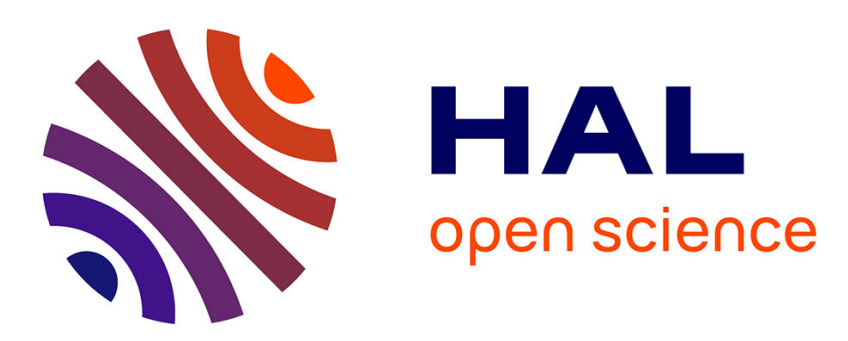

\title{
Categorizing chlordecone potential degradation products to explore their environmental fate
}

Pierre Benoit, Laure Mamy, Rémi Servien, Ziang Li, Eric Latrille, Virginie Rossard, Fabienne Bessac, Dominique Patureau, Fabrice Martin-Laurent

\section{- To cite this version:}

Pierre Benoit, Laure Mamy, Rémi Servien, Ziang Li, Eric Latrille, et al.. Categorizing chlordecone potential degradation products to explore their environmental fate. Sciences of the total Environment, 2017, 574, pp.781-795. 10.1016/j.scitotenv.2016.09.094 . hal-01376211

\section{HAL Id: hal-01376211 \\ https://hal.science/hal-01376211}

Submitted on 6 Oct 2016

HAL is a multi-disciplinary open access archive for the deposit and dissemination of scientific research documents, whether they are published or not. The documents may come from teaching and research institutions in France or abroad, or from public or private research centers.
L'archive ouverte pluridisciplinaire HAL, est destinée au dépôt et à la diffusion de documents scientifiques de niveau recherche, publiés ou non, émanant des établissements d'enseignement et de recherche français ou étrangers, des laboratoires publics ou privés. 
1 Categorizing chlordecone potential degradation products to explore their 2 environmental fate

3

4 Pierre Benoit ${ }^{\mathrm{a},}$, Laure Mamy ${ }^{\mathrm{a}}$, Rémi Servien ${ }^{\mathrm{b}}$, Ziang $\mathrm{Li}^{\mathrm{a}}$, Eric Latrille ${ }^{\mathrm{c}}$, Virginie 5 Rossard $^{\mathrm{c}}$, Fabienne Bessac $^{\mathrm{d}}$, Dominique Patureau ${ }^{\mathrm{c}}$, Fabrice Martin-Laurent ${ }^{\mathrm{e}}$

6

$7 \quad{ }^{a}$ UMR ECOSYS, INRA, AgroParisTech, Univ. Paris-Saclay, 78850 Thiverval-Grignon, France

$8{ }^{b}$ UMR TOXALIM, INRA, Univ. de Toulouse, 31027 Toulouse, France

$9{ }^{c}$ LBE, INRA, 11100 Narbonne, France

d INPT-Ecole d'Ingénieurs de Purpan, Univ. de Toulouse, 31076 Toulouse, France;

11 CNRS/Univ. De Toulouse (Paul Sabatier)-UMR 5626, Laboratoire de Chimie et Physique 12 Quantiques, 31062 Toulouse, France

$13{ }^{e}$ UMR AgroEcologie, INRA, AgroSup Dijon, Univ. Bourgogne Franche-Comté 21065 Dijon, 14 France

16 Corresponding author.

17 E-mail address: pierre.benoit@grignon.inra.fr (P. Benoit)

\section{GRAPHICAL ABSTRACT}

\section{In silico categorization of putative transformation products (TPs) of chlordecone using TyPol (Typology of Pollutants) tool}

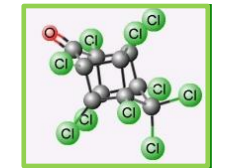

Koc, DT50, BCF

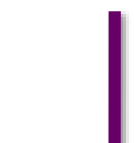

Transformation

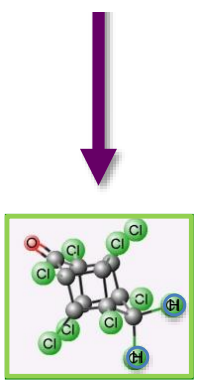

Environmental behaviour?

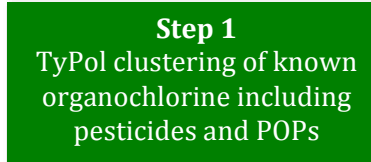

$\Rightarrow$ Clustering from molecular descriptors (MW, $E_{\text {номо...) and environmental }}$ parameters (Koc, DT50...)

$\Rightarrow$ Clustering from molecular descriptors $\left(M W, E_{\text {номо } . . .)}\right.$

\section{Step 2}

TyPol clustering including

putative chlordecone TPs
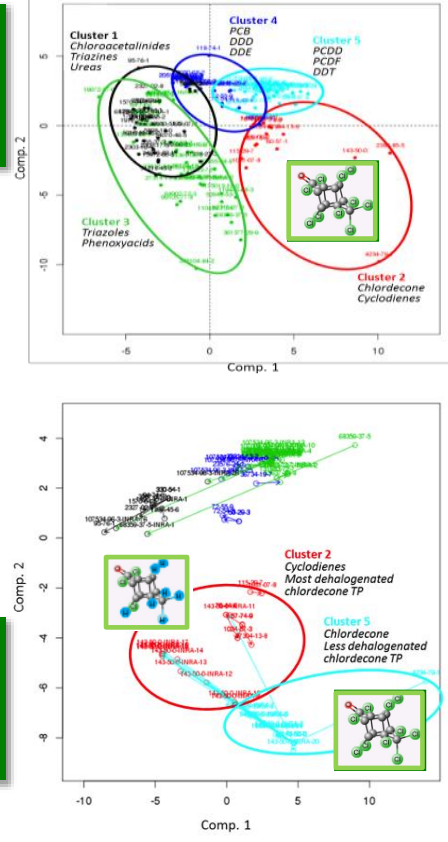

Step 3 Deduction of environmental parameters for the unknown TPs 


\section{ABSTRACT}

Chlordecone $\left(\mathrm{C}_{10} \mathrm{Cl}_{10} \mathrm{O}\right.$; CAS number 143-50-0) has been used extensively as an organochlorine insecticide but is nowadays banned and listed on annex A in The Stockholm Convention on Persistent Organic Pollutants (POPs). Although experimental evidences of biodegradation of this compound are scarce, several dechlorination products have been proposed by Dolfing et al. (2012), using Gibbs free energy calculations to explore different potential transformation routes. We here present the results of an in silico classification (TyPol - Typology of Pollutants) of chlordecone transformation products (TPs) based on statistical analyses combining several environmental endpoints and structural molecular descriptors. Starting from the list of putative chlordecone TPs and considering available data on degradation routes of other organochlorine compounds, we used different clustering strategies to explore the potential environmental behaviour of putative chlordecone TPs from the knowledge on their molecular descriptors. The method offers the possibility to focus on TPs present in different classes and to infer their environmental fate. Thus, we have deduced some hypothetical trends for the environmental behaviour of TPs of chlordecone assuming that TPs, which were clustered away from chlordecone, would have different environmental fate and ecotoxicological impact compared to chlordecone. Our findings suggest that mono and di-hydrochlordecone, which are TPs of chlordecone often found in contaminated soils, may have similar environmental behaviour in terms of persistence.

Keywords: Organochlorine pesticides, Biodegradation, Molecular modeling, Partial least squares

\section{HIGHLIGHTS}

- TyPol, an in silico typology, was used to categorize 170 organochlorine molecules

- Clustering used both molecular descriptors and environmental behaviour

- Parent and transformation products represented various chemical families

- 20 chlordecone putative transformation products (TPs) were categorized

- Combining two clustering allowed assessing the potential fate of chlordecone TPs 


\section{Introduction}

In the French West Indies (FWI), chlordecone $\left(\mathrm{C}_{10} \mathrm{Cl}_{10} \mathrm{O}\right.$; CAS number 143-50-0 decachlorooctahydro-1,3,2-metheno-2Hcyclobuta[c,d]pentalen-2-one) has been largely used on banana plantations over the 1978-1993 period to control banana weewil. Its persistence in the agricultural soils of the FWI (i.e., 20,000 ha that represent up to $25 \%$ of the agricultural surface of the FWI) was estimated to last for several decades in Nitisol, centuries in Ferralsol, and half a millennium in Andosol soils (Cabidoche et al., 2009).

This organochlorine insecticide is now banned and listed in annex A of the Stockholm Convention on Persistent Organic Pollutants (POPs) but its former use has induced a general and important contamination of rivers, springs, and drinking water as well as coastal ecosystems of the FWI (Coat et al., 2011) as revealed by investigation of the French National Action Plan for chlordecone (PNAC 2008-2010). In such context, finding strategies to remediate and/or mitigate this contamination on the very long-term is a great challenge and, from this point of view, the FWI represent an open field for remediation (Cabidoche and Jeannoyer, 2011; Levillain et al., 2012).

There is no clear cut evidence of microbial chlordecone degradation under aerobic conditions. Indeed Orndorff and Colwell (1980) proposed that Pseudomonas aeruginosa strain $\mathrm{KO} 3$ and a bacterial consortium isolated from Hopewell plant sewage sludge under aerobic conditions transform chlordecone into monohydro-chlordecone and di-hydro-chlordecone. However, these results have been criticized by Cabidoche et al. (2009) because the initial contents in mono-hydro- and di-hydro-chlordecone, known to be by-products of the synthesis contaminating the chlordecone, have not been measured. This lack is compromising the proposed results because detection of chlordecone TPs can be the result of incomplete chlorination of chlordecone during synthesis and not to microbial biodegradation. Later on, George and Claxton (1988) studied chlordecone degradation catalyzed by three Pseudomonas spp. showing that after two weeks of incubation chlordecone reached only $15-25 \%$ of initial concentration with a relatively high uncertainty of $10 \%$ on chlordecone HPLC concentration measurements. In addition, in non-inoculated control, mono- and dihydro chlordecone were detected as well. A poor bacterial growth was recorded and, consequently, the authors concluded that due to its important chlorination, chlordecone was a poor carbon source for bacterial growth. However, a recent study based on a large data set of 881 field soils of the FWI showed a significant increase of the 
5bhydrochlodecone/chlordecone ratio in the soils 25 times greater than in commercial formulations which suggested that natural transformation into 5b-hydrochlodecone over the long term occurred in these soils (Devault et al., 2016).

Under anaerobic conditions, a pure culture of Methanosarcina thermophila grown on acetate was shown to convert chlordecone to polar and nonpolar products (Jablonski et al., 1996). Interestingly, similar pattern of soluble chlordecone decomposition products were obtained with reduced vitamin B12 and reduced coenzyme F430 isolated from $M$. thermophila. More recently, Pseudonocardia sp. KSF27 isolated from a soil repeatedly treated with endosulfan was shown to also degrade dieldrin and other organochlorine insecticides such as chlordecone but without providing information on the degradation pathway (Sakakibara et al., 2011).

In France, giving the environmental and health problem caused by chlordecone contamination in the West Indies, several research programs have recently been carried out on soil bioremediation. Search for chlordecone-degrading microorganisms under anaerobic and aerobic conditions remains a big challenge due to the lack of experimental evidences of degradation products in soil environment. Indeed, only few measured data on the identification of chlordecone TPs are available showing traces of the TP 5b-hydrochlodecone in some Andosol, Nitisol, and Ferralsol soil samples (Devault et al., 2016; Martin-Laurent et al., 2014). Recently, Fernandez-Bayo et al. (2013) gave evidence for a weak but measurable mineralization of ${ }^{14} \mathrm{C}$-chlordecone in an Andosol from Guadeloupe in aerobic conditions reaching $4.9 \%$ of the ${ }^{14} \mathrm{C}$ chlordecone initially added in the topsoil $(0-20 \mathrm{~cm})$ and $3.2 \%$ in the below horizon (30$60 \mathrm{~cm}$ ) over a $230 \mathrm{~d}$ period of incubation. The absence of ${ }^{14} \mathrm{CO}_{2}$ evolution in sterile soil microcosms led the authors to conclude that chlordecone mineralization was biotic being most likely catalyzed by microorganisms (Fernandez-Bayo et al., 2013).

Dolfing et al. (2012) conducted a theoretical study using Gibbs free energy calculations to explore the thermodynamic feasibility of different chlordecone potential degradation routes. By performing ab initio quantum chemical calculations to estimate molar values of $\Delta \mathrm{fHm}^{\circ}$ and $\Delta \mathrm{fGm}^{\circ}$ for chlordecone and selected dechlorination products, they have estimated the energetics of the degradation and dechlorination of chlordecone under a variety of redox conditions. They ended up with the proposal of a list of 20 potential TPs and concluded that there were no thermodynamic reasons why chlordecone-respiring or -fermenting organisms should not exist. 
Complementary information could be brought by clustering approaches based on the relationships between molecular properties and environmental fate of organic compounds. With this aim, we recently developed 'TyPol' (Typology of Pollutants), a classification method based on statistical analyses combining several environmental endpoints (i.e. environmental parameters such as sorption coefficient, degradation halflife or bioconcentration factor), and structural molecular descriptors (number of atoms in the molecule, molecular surface, dipole moment, energy of orbitals...). This approach also allows to focus on TPs present in different classes and to infer possible changes in environmental fate consecutively to different degradation processes (Servien et al., 2014). Starting from the list of chlordecone TPs proposed by Dolfing et al. (2012) and considering available literature data on degradation routes of other organochlorine compounds, we conducted a study using TyPol to explore the potential environmental behaviour of chlordecone TPs based on their molecular properties.

\section{Materials and methods}

\subsection{Clustering methodology}

The TyPol tool permits to classify organic compounds, and their transformation products, according to both their behaviour in the environment and their molecular properties. The calculation of molecular descriptors is performed using an in silico approach, while the environmental endpoints (i.e. environmental parameters) are extracted from several available databases and literature. The strategy relies on partial least squares analysis and hierarchical clustering (see below 2.5. Statistical treatments). The robustness of the TyPol method was assessed on a list of 215 organic compounds using a cross-validation algorithm. The information system is based on a management system for relational database MySQL DBMS-R (version 5.1), an Apache web server (version 2.2), and the statistical $\mathrm{R}$ software (also used for graphs). More details concerning TyPol can be found in Servien et al. (2014).

\subsection{Environmental parameters}

Seven environmental parameters are considered in TyPol in order to cover the main processes involved in the behaviour of organic substances: water solubility $(S w)$ and octanol-water partition coefficient $(K o w)$ to describe dissolution; vapor pressure $\left(P_{\text {vap }}\right)$ and Henry's law constant $\left(K_{H}\right)$ for volatilization from soil and plant, and water, respectively; adsorption coefficient normalized to soil carbon organic content (Koc) for 
adsorption; half-life (DT50) for degradation; and bioconcentration factor $(B C F)$ for ecotoxicity (Servien et al., 2014).

\subsection{Molecular descriptors}

Forty relevant molecular descriptors are considered in TyPol. They have been selected from a literature review of QSARs (Quantitative Structure Activity Relationships) developed to predict different environmental processes (Mamy et al., 2015). We focused on QSARs only built with structural molecular descriptors (number of atoms, molecular surface, dipole moment, energy of the orbitals...) rather than characteristics such as $S w$ or Kow. Molecular descriptors are calculated using several software (ChemOffice Ultra 12.0, Dragon 5.5).

\subsection{Database implementation}

A literature survey was done to provide a list of compounds (parent and transformation product) representing different mechanisms - i.e reductive dechlorination, hydroxylation, oxidation, epoxidation, photolysis, hydrolysis - involved in their abiotic or biotic transformations. In total, 170 chlorinated compounds were listed and added to the TyPol database by implementing data on environmental parameters when available (130 compounds). The idea was to cover a broad spectrum of compounds such as organochlorine pesticides but also PCB, PCDD and PCDF so that clustering could segregate chlorinated compounds according to their molecular properties and environmental behaviour. TPs were looked for these different chemical families (Hester and Harrison, 1996; Roberts and Hudson, 1999). Molecular descriptors were calculated and inserted for each compound. For chlordecone, 20 dechlorinated TPs proposed by Dolfing et al. (2012) as well as chlordecol were considered.

\subsection{Statistical treatments}

In TyPol, the PLS (Partial Least Squares) model is carried out to find the multidimensional directions in the $\mathrm{X}$ observable variables (i.e. molecular descriptors) space that explains the maximum multidimensional variance direction in the $\mathrm{Y}$ predicted variables (i.e. environmental parameters) space. The optimal number of PLS components to perform clustering is selected according to Wold rules (Wold, 1978). In addition, we use the NIPALS (Non-linear Iterative PArtial Least Squares) algorithm, which allows performing PLS without removing the individuals with missing values 
and without estimating these missing values (Tenenhaus, 1998). After PLS analysis, a hierarchical clustering algorithm is used on the X and Y PLS axes to categorize the molecules by assignment of similar compounds into one cluster. At each step, the final number of clusters is chosen by comparison of heights in the dendrogram, a statistical map resuming Ward clustering. Minimization of intra-variability and maximization of inter-variability are the parameters retained to choose the most appropriate number of clusters (Servien et al., 2014).

We used TyPol in two manners. In a first approach, TyPol was used to identify relationships between molecular descriptors and environmental fate processes among several clusters of organochlorine molecules by considering molecular descriptors and available environmental parameters. In a second approach, TyPol clustering was performed by including chlordecone TPs and using only the molecular descriptors as their environmental parameters are unknown. In this case the observable and the predicted variables are the same (i.e the molecular descriptors) and the PLS is equivalent to a Principal Component Analysis (PCA). The clustering was further used to estimate trends for the environmental parameters of chlordecone TPs clusters by comparing molecular descriptors of chlordecone TPs to those of 113 other organochlorine compounds of the database and 16 organochlorine TPs for which environmental parameters such as sorption coefficient or degradation half-life were known. The dataset generated allowed discussing and proposing hypothetical environmental behaviour of the different chlordecone TPs.

\section{Results and discussion}

\subsection{Degradation routes of organochlorine pesticides}

As reviewed by Roberts and Huston (1999), organochlorine insecticides such as DDT and cyclodienes were historically among the first major classes of synthetic chemicals that have been restricted because of their high persistence, high potential of bioaccumulation and ubiquitous contamination. Main degradation pathways of these compounds reported in literature are oxidation, epoxidation and dechlorination reactions (Table 1).

The most important transformation reactions in soils of DDT are dehydrochlorination to DDE and reductive dechlorination to DDD. Due to their recalcitrance, these two TPs are still frequently found in environmental samples although they can also undergo 
reductive dehalogenation (Subba-Rao and Alexander, 1985) or hydroxylation of aliphatic moieties (Bumpus and Aust, 1987).

Cyclodiene insecticides share few structural similarities with the bishomocubane structure, which constitutes the skeleton of chlordecone and of its derivatives (Francis and Metcalfe, 1984). Chlordane has a variety of metabolic pathways including oxidation, reductive dechlorination, hydroxylation and epoxidation in soils leading to TPs such as dichlorchlordene, oxychlordane, heptachlor, heptachlor epoxide or chordene chlorohydrin (Table 1). Endosulfan is readily hydrolysed in water to the diol form but it is moderately persistent in soil where the major TP is the endosulfan sulfate, which is more persistent than the parent compound.

Up to now, mostly 5b-hydrochlodecone and dihydrochlordecone have been identified as chlordecone TPs mostly concerned (Martin-Laurent et al., 2014; Orndorff and Colwell, 1980) suggesting that in the soil environment hydroxylation and dechlorination are the most probable transformation reactions. The bishomocubane structure (typical for chlordecone and congeners) provides a great stability due to the $10 \mathrm{Cl}$ atoms which promotes electron delocalization and limits the possibilities of oxidation of the $\mathrm{C}$ atoms, explaining the great recalcitrance of chlordecone in aerobic conditions. On the contrary, the high chlorine content of the chlordecone molecule makes anaerobic dechlorination the most likely mode of initial transformation reaction (Table 1) as already shown for an important number of different aromatic and aliphatic compounds, including chlorinated ethylenes, PCBs, dioxins and furans, which are degraded by reductive dechlorination (Field and Alvarez, 2008 a and b; Schanke and Wackett, 1992). Dechlorination of chlordecone may occur in reductive environmental conditions and is the most probable route according to thermodynamic approach based on Gibbs free energy calculations (Dolfing et al., 2012).

\subsection{Clustering using molecular descriptor and environmental parameters}

One hundred and thirty organochlorine compounds were used in this first clustering (Fig.1, Table A1). The number of PLS components was chosen equal to four according to Wold rules (Wold, 1978). The PLS model was characterized by the following statistical results: $\mathrm{R}_{\mathrm{X}}^{2}=0.62, \mathrm{R}_{\mathrm{Y}}^{2}=0.70$ and $\mathrm{Q}_{\mathrm{Y}}^{2}=0.40$ indicating that it was a satisfactory model representative for the different compounds included in TyPol. The main characteristic of the first component, which explains $34 \%$ of the variance of the molecular descriptors and $47 \%$ of the variance for the environmental parameters, is the 
strong positive loadings for all the geometric and topological descriptors, and constitutional descriptors like the number of chlorine or halogen atoms (Fig. 2). A contrario, the dipole moment and the total energy have strong negative effects therefore have an opposite effect. The second axis explains $28 \%$ of the variance of the molecular descriptors and $23 \%$ of the variance for the environmental parameters. On this axis, variables such as the number of chlorine or halogen atoms have a positive loading whereas the number of rotatable, double or simple bonds or the number of hydrogen, oxygen or total atoms have a negative loading (Fig. 2). Fig. 2 also shows that many variables seem to be correlated, mainly the different connectivity and valence connectivity indices.

The selection of the number of clusters was performed by plotting the heights of the dendrogram's node and looking for a break. The results showed that the best choice, minimizing intra-variability and maximizing inter-variability, was to classify the compounds in 5 clusters. The size of the five clusters varied from 15 to 32 compounds (Fig. 1, Table A1), each cluster being characterized by specific features. Fig. 3 shows the range of variations of the values of the 7 environmental parameters for each of the 5 clusters. The trigger value of $P_{v a p}$ is indicated to differentiate volatile and non-volatile compounds (there is no trigger value for $K_{H}$, FOCUS, 2008), that of Koc to differentiate mobile and non-mobile compounds (Mackay, 2006), that of DT50 to differentiate persistent and non-persistent compounds (1107/2009 EC, 2009), and that of BCF to differentiate compounds having or not a potential of bioaccumulation (1107/2009 EC, 2009) (Fig. 3). Depending on the values of $P_{\text {vap }}$, Koc, DT50 and/or BCF, each of the five clusters aggregate various organochlorine compounds having (or not) risks for air, water and/or soil contamination and/or high ecotoxicity. The importance of the different environmental parameters in the clustering can be evaluated on the correlation circle (Fig. 2) showing that BCF, Kow (positive loadings) and $S w$ (negative loading) are strongly related to the first component. $P_{v a p}$ and $K_{H}$ have a positive loading on the second axis. DT50 and Koc are the parameters which have low influence on the two main PLS components of the clustering (Fig. 2)

The cluster 1 contains 31 molecules and groups together chloroacetanilides, chlorinated $s$-triazines, ureas and triallates inputted in TyPol. This cluster is made of compounds characterized by an important dipole moment and high values of total energy, whereas polarizabilities and the different connectivity indices are low (Table A2). These compounds have low number of chlorine atoms, low molecular weight and 
low Connolly molecular surface area. Median values of $S w$ are high (median $\log _{10} S w=$ 1.55) although $K o c$ have medium to relatively high values (median $\log _{10} K o c=2.34$ ). They have low DT50 (Fig. 3) suggesting that they have a low persistence in the environment (Regulation EC 1107/2009, 2009). They also have relatively low BCF suggesting that these compounds are not susceptible to bioaccumulate in living organisms (i.e. low ecotoxicity, Regulation EC 1107/2009, 2009). Finally, compounds gathered in cluster 1 have medium $K_{H}$ values (i.e. a medium volatility from water) but relatively high values of $P_{\text {vap }}$ so high volatility from soil and plant, and potential of transfer to atmosphere (FOCUS, 2008). Few compounds of this cluster are closed to those of cluster 2 in the two X-axes of the PLS, but differences between these molecules are more easily noticeable in the Y-axes of the PLS.

The cluster 2 contains mirex, kelevan and chlordecone as well as other organochlorine pesticides such as aldrin, chlordane, endosulfan, heptachlor and their known TPs such as oxychlordan, heptachlor epoxide, endosulfan sulfate. The 3 bishomocubanes (chlordecone, mirex and kelevan) are relatively detached from the other molecules in the PLS projection. As discussed above, these three compounds have a very particular chemical structure (bishomocubane family) responsible for their high persistence (high DT50) in the environment. They have very high values of connectivity or valence connectivity indices, polarizability, molecular weight, number of chlorine and other halogen atoms; and low values of number of multiple bonds, total energy, HOMO energy, dipole moment and medium value for LUMO energy (Table A2). The number of rotatable and aromatic bonds is extremely low. Considering the environmental parameters, they have low $S w$ but rather low Koc (median $\log _{10} K o c=$ 1.76), medium to high $B C F$ indicating their that is high ecotoxicity towards living organisms, and high $K_{H}$ (Dolfing et al., 2012; PPDB, 2013) (Fig. 3).

The cluster 3 is composed of 32 compounds with several chemical families represented: triazoles, phenoxyacids, strobilurins, ketones. These compounds have high dipole moment, high polarizability and low total energy. The number of $\mathrm{Cl}$ atoms is low whereas the number of $\mathrm{O}$ and $\mathrm{N}$ atoms is the highest of all clusters. Valence connectivity indices and connectivity indices for zero and first order are high as well as the Connolly molecular surface area (Table A2). These compounds also have low DT50 (rapid dissipation and low persistence), medium Koc (medium mobility), high $S w$ (and low Kow), and low BCF suggesting their low ecotoxicity (Fig. 3). 
The cluster 4 is composed of 25 compounds, most of them being the PCBs inputted in TyPol and some degradation products of DDT (DDE, DDD). This cluster is characterized by low polarizability, low dipole moment and low connectivity indices. The number of $\mathrm{Cl}$ atoms is low as well as the number of $\mathrm{O}$ and $\mathrm{N}$ atoms. The number of aromatic bonds is high (Table A2). It has the lowest DT50 of the five clusters indicating their relatively low persistence in the environment. Compounds of cluster 4 have high values of $B C F$ indicating their high ecotoxicity. They also have high $K o w$ and low $S w$, high $P_{v a p}$ and $K_{H}$, indicating their high potential for volatilization.

The cluster 5 contains 27 molecules with all PCDD and PCDF and few organochlorine insecticides such as DDT. They have high values of polarizability and valence and connectivity indices, whereas the total energy, LUMO energy and the dipole moment are very low. This group is characterized by low number of $\mathrm{N}$ and $\mathrm{O}$ atoms and by contrast high number of $\mathrm{Cl}$ atoms (Table A2). This feature, in combination with high molecular weights and low number of hydrogen atoms is related to low values of $S w$ (the lowest among the 5 clusters) and high values of Kow, and to the highest values of $B C F$. The compounds of cluster 5 also have the highest DT50 among the 5 clusters, which means very high persistence in soils (Regulation EC $1107 / 2009$, 2009) (Fig. 4). Finally, they have low values of $P_{v a p}$ and $K_{H}$ indicating a moderate risk of transfer to the atmosphere (Fig. 3).

\subsection{Clustering using molecular descriptors only}

We have added to the 130 organochlorine compounds inputted in TyPol, the 19 TPs of chlordecone proposed by Dolfing et al. (2012) as well as 21 putative TPs of tebuconazole containing $\mathrm{Cl}$ atoms recently screened by Storck et al. (2016) (Table 2). With this new dataset a second TyPol clustering was carried out and four PLS components were selected as described above. The PLS model had good statistical results: $\mathrm{R}^{2}=0.65$, and $\mathrm{Q}^{2}=0.81$. It has to be noted that the PLS analysis was only performed on the molecular descriptors. Therefore, the $\mathrm{X}$ observable variables are also the Y predicted variables. Nevertheless, obtained results showed that the PLS was a good model for the different compounds included in TyPol. The first and second components explained $39 \%$ and $26 \%$ of the variance, respectively. The second PLS is sharing some similarities with the first one. The main characteristic of component 1 was also the strong positive loadings for some topological descriptors such as the different connectivity indices as well as the polarizability and strong negative loading of the total 
energy. However, by comparison with the first PLS, the dipole moment and number of chlorine and halogens had no influence on this first component. On the contrary, these variables are well distributed along the second component. On this second axis, variables such as the number of chlorine or halogen atoms have this time a negative loading whereas HOMO energy, the number of hydrogen, oxygen, the number of multiple, aromatic and rotatable bonds have a positive loading (Fig. 4). As for the first PLS, the LUMO energy has a poor influence on the 2 first components.

The size of the five clusters varied from 12 to 50 compounds (Fig. 5, Table A3). Compared to the first classification, several compounds moved from one group to another one most likely due to the fact that environmental parameters were not taken into account. For instance, the cluster 1 still contains phenylureas, triallates and striazine pesticides but includes also phenoxyacids and few TPs of tebuconazole and small biphenyls. Also, clustering on molecular descriptors separated better chlordecone and analog cyclodienes (mirex, kelevan) and a large part of the putative TPs from the other organochlorine compounds (Fig. 5; Table A3). All these compounds are now found in cluster 5 whereas they were associated to other organochlorine insecticides in the first classification (cluster 2). This more homogeneous composition of cluster 5 around compounds characterized by a bishomocubane skeleton is probably due to the fact that classification was done only with the molecular descriptors. In comparison to the other organochlorine pesticides (still in cluster 2), the chlordecone cluster has several features in common: low number of multiple bound, no rotatable bound, low dipolar moment and high polarizability (Table A4). But the chlordecone cluster was made of compounds characterized by typical values of the following molecular descriptors: they have the lowest total energy and HOMO energy, the highest connectivity indices, the highest number of $\mathrm{Cl}$ atoms and the highest molecular weight of all clusters. Such specificities are in accordance with (i) the results of our first clustering which has shown that such trends of molecular descriptors were associated with high values of $D T 50$ and $B C F$ (clusters 2 and 5 of the first clustering) and (ii) the low biodegradation of chlordecone observed in the environment (Cabidoche et al., 2009; Dolfing et al., 2012; Fernandez-Bayo et al., 2013; Martin-Laurent et al., 2014).

An important result was that the main features of molecular descriptors remain quite similar from one classification to another one. As in the first classification, cluster 1 was characterized by low polarizability values, low connectivity and valences indices, low number of $\mathrm{Cl}$ atoms and molecular weight (Table A4). Total energy and dipole moment 
had high values. Cluster 2 still contained the organochlorine insecticides and additionally, the more dechlorinated TPs of chlordecone. It kept the main features for the molecular descriptors: high values of connectivity or valence connectivity indices, polarizability, molecular weight, number of chlorine and other halogen atoms; and low values of number of multiple and rotatable bonds, low values of total energy and HOMO energy (Table A4). The dipole moment value was a bit higher than in the first classification. Cluster 3 containing triazoles has now incorporated most of the tebuconazole TPs (Table A3). This group is characterized by high dipole moment, high polarizability and low total energy. The number of $\mathrm{Cl}$ atoms was low whereas the number of $\mathrm{O}$ and $\mathrm{N}$ atoms was the highest of all clusters. Valence connectivity indices and connectivity indices for zero and first order were high as well as the Connolly molecular surface area (Table A4). Cluster 4 now gathered all PCDD, PCDF and the majority of PCBs and DDT (Table A3). Molecular descriptors have kept the main features: low polarizability; low dipole moment; low number of $\mathrm{Cl}, \mathrm{O}$ and $\mathrm{N}$ atoms; high number of aromatic bonds. Compared to the first clustering, polarizability as well as the connectivity indices had now medium values in the cluster 4 (Table A4).

\subsection{Exploring the environmental fate of putative chlordecone transformation products} The similarities of molecular descriptors distribution values in the two clustering can be used to deduce parameters for compounds for which environmental parameters are unknown. This is done assuming that compounds gathered in the same cluster on the basis of their molecular descriptors have similar environmental parameters (Storck et al., 2016).

Sixty-two parent-TP couples have been used for the TyPol clustering using only molecular descriptors. $74 \%$ of TPs were found in the same cluster than their parent molecule suggesting that most of the TPs may have similar behaviour in the environment than parent compounds from which they derived. For organochlorine pesticide such as DDT and chlordane, TPs were always found in the cluster of the parent molecule (Figure 6). This suggests that their transformation changed neither their molecular properties nor their environmental behaviour.

Concerning chlordecone and its potential TPs, we can notice that TPs gathered in different clusters according to the extent of their dechlorination. When more than $4 \mathrm{Cl}$ atoms were replaced by $\mathrm{OH}$ then putative TPs gathered to cluster 2 (pentahydrochlordecone) or cluster 1 (hepta to nona-hydrochlordecone) and not to cluster 5 
like parent compound. In the first case, cluster 2 regrouped organochlorine pesticides such as DDT and chlordane but also compounds such as chlorinated dioxin, furans and high molecular weight PCBs whereas cluster 1 was containing low molecular weight PCBs and pesticides such as 2,4D, dicamba, atrazine and chlortoluron. Less dechlorinated compounds as well as chlordecol, remained in cluster 5 suggesting that mono-hydro to tetra-hydrochlordecone could have strong similarities with chlordecone, mirex and kelevan.

Looking more carefully into the analysis of molecular descriptors of the corresponding clusters of chlordecone (cluster 5), organochlorine insecticides (cluster 2) and low molecular weight and more polar pesticides (cluster 1) showed that median values of molecular descriptors were quite discriminant for these 3 groups (see 3.3. Clustering using molecular descriptors only). Clusters 5 and 2 shared common features such as low dipole moment and high polarizability, low number of multiple bound, no rotatable bound, low total energy and HOMO energy, high connectivity indices, high number of $\mathrm{Cl}$ atoms and high molecular weight. But, as pointed out before, the chlordecone cluster had more extreme values for the total energy, connectivity indices, dipole moment and $\mathrm{Cl}$ atoms number. On the opposite, molecules of cluster $1 \mathrm{had}$ higher dipole moment, higher total energy, lower polarizability, much lower values of connectivity and valence indices, lower number of $\mathrm{Cl}$ atoms and lower molecular weight.

Using the results of the first clustering resulting from the analysis of both environmental parameters and molecular descriptors we deduced some trends by linking molecular descriptors features to values of environmental parameters such as DT50, $K o c, P_{\text {vap }}$ and $B C F$ for the clusters obtained for chlordecone, organochlorine insecticides and low molecular weight and more polar pesticides. Based on this deductive approach one could hypothesize that the most dechlorinated chlordecone TPs (hepta to nonahydrochlordecone) may have environmental properties similar to that of low molecular weight and more polar pesticides: low DT50 (rapid dissipation), medium Koc (medium mobility), high $S w$ (and low Kow), and low BCF so low ecotoxicity. On the contrary, TPs less heavily dechlorinated such as penta-hydrochlordecone may have like its parent compound very high values of $B C F$ and high DT50, which means a very long persistence in soils and very high risk for bioaccumulation and transfer all along the food chain. Finally the lowly dechlorinated TPs are close to the parent compound and consequently are expected to exhibit similar trends in terms of environmental fate and 
ecotoxicological impacts. They would be characterized by a very long persistence in soils and very high risk for the transfer in the food chain but also in the environment via mobility from soil to water compartment through slow leaching processes since the chlordecone cluster is characterized by relatively low Koc. As pointed out by Dolfing et al. (2012), reductive dechlorination of chlordecone is thermodynamically favorable, but whether this reaction can proceed at environmentally significant rates and/or at rates, which can sustain growth of organisms catalyzing such reactions, remains unproven yet.

\section{Conclusion}

We used in silico molecular typology to explore the potential fate of putative chlordecone TPs. The TyPol approach applied implied two steps. A first clustering step served to search for possible correlations between molecular descriptors of organochlorine compounds and their environmental parameters covering biodegradation, mobility and bioaccumulation processes. From the calculation of molecular descriptors for a series of existing or putative TPs, we performed a second clustering where the filiation between parent and TPs was accounted for. By comparing the two clustering results, we deduced environmental parameters for chlordecone TPs and discussed hypothetical trends for their environmental behaviour.

Recent experimental studies exploring the degrading capacities of different type of soils and of different soil microorganisms have confirmed that biodegradation of chlordecone is very low and slow. Our findings suggest that lowly dechlorinated TPs such as mono and di-hydrochlordecone, often found in chlordecone-contaminated soils, may have similar environmental behaviour than chlordecone in terms of persistence and transfer in the environment, bioaccumulation and transfer all along the food chain. By contrast, more heavily dechlorinated TPs may have very different environmental parameters more favorable than those of chlordecone but unfortunately, to our best knowledge, the conditions leading to their formation remain unknown.

\section{Acknowledgments}

The authors acknowledge the Projet Innovant of the "Environnement et Agronomie" Department of INRA and the AIP DEMICHLORD (Etudes exploratoires de la dégradation microbienne de la chlordécone) of INRA for financial supports, and the 
494

495

496

497

498

499

500

501

502

503

504

505

506

507

508

509

510

511

512

513

514

515

516

517

518

519

520

521

522

523

524

525

526

FIRE (Fédération Ile-de-France de Recherche sur l'Environnement) for Ziang Li's master grant.

\section{References}

Bristeau S., Amalric L., Mouvet C., 2014. Validation of chlordecone analysis for native and remediated French West Indies soils with high organic matter content. Anal Bioanal Chem, 406,1073-1080

Bumpus J.A., Aust S.D., 1987. Biodegradation of DDT 1,1,1-dichloro-2,2-bis-4(chlorophenyl)ethane by the white rot fungus Phanerochaete crysosporium. Appl Environ Microbiol 53, 2001-2008.

Cabidoche Y-M., Lesueur-Jannoyer M., 2011. Long term pollution of soils in French West Indies: how to manage chlordecone contamination? Innov Agron, 16, 117-133.

Cabidoche Y-M., Achard R., Cattan P., Clermont-Dauphin C., Massat F., Sansoulet J., 2009. Long-term pollution by chlordecone of tropical volcanic soils in the French West Indies: a simple leaching model accounts for current residue. Environ Pollut 157, 1697-1705.

Coat S., Monti D., Legendre P., Bouchon C., Massat F., Lepoint G., 2011. Organochlorine pollution in tropical rivers (Guadeloupe): role of ecological factors in food web bioaccumulation. Environ Pollut 159,1692-1701.

Devault D.A., Laplanche C., Pascaline H., Bristeau S., Mouvet C., Macarie H., 2016. Natural transformation of chlordecone into 5b-hydrochlordecone in French West Indies soils: statistical evidence for investigating long-term persistence of organic pollutants. Environ Sci, Poll Res, 23, 81-97.

Dolfing J., Novak I., Archelas A., Macarie H., 2012. Gibbs free energy of formation of chlordecone and potential degradation products: implications for remediation strategies and environmental fate. Environ Sci Technol 46, 8131-8139.

Fernández-Bayo J.D., Saison C., Voltz M., Disko U., Hofmann D., Berns A.E., 2013. Chlordecone fate and mineralisation in a tropical soil (andosol) microcosm under aerobic conditions. Sci Total Environ 463-464, 395-403.

Field J.A., Sierra-Alvarez R., 2008a. Microbial degradation of chlorinated dioxins Chemosphere 71, 1005-1018.

Field J.A., Sierra-Alvarez R., 2008b. Microbial degradation of polychlorinated biphenyls. Environmental Pollution 155, 1-12 
Francis B.M., Metcalf R.L., 1984. Evaluation of mirex, photomirex and chlordecone in the terrestrial aquatic laboratory model ecosystem. Environ Health Perspect, 54, 341346.

George, S.E., Claxton, L.D., 1988. Biotransformation of chlordecone by Pseudomonas species. Xenobiotica 18, 407-416.

Hester R.E., Harrison R.M., 1996. Chlorinated Organic Micropollutants. Issues in Environmental Science and Technology, 6. The Royal Society of Chemistry, Information Services Cambridge, UK.

Jablonski P.E., Pheasant D.J., Ferry J.G., 1996. Conversion of Kepone by Methanosarcina thermophila. FEMS Microbiol Lett 139(2-3), 169-173.

Levillain J., Cattan P., Colin F., Voltz M., Cabidoche Y-M., 2012. Analysis of environmental and farming factors of soil contamination by a persistent organic pollutant, chlordecone, in a banana production area of French West Indies. Agric Ecosyst Environ 159, 123-132.

Mackay, D.S.-C., 2006. Handbook of physical-chemical properties and environmental fate for organic chemicals. CRC Press Taylor and Francis.

Mamy L., Patureau D., Barriuso E., Bedos C., Bessac F., Louchart X., Martin-Laurent F., Miege C., Benoit P., 2015. Prediction of the Fate of Organic Compounds in the Environment From Their Molecular Properties: A Review. Critical Reviews in Environmental Science and Technology 45, 1277-1377.

Martin-Laurent F., Sahnoun M.M., Merlin C., Vollmer G., Lübke M., 2014. Detection and quantification of chlordecone in contaminated soils from the French West Indies by GC-MS using the ${ }^{13} \mathrm{C}_{10}$-chlordecone stable isotope as tracer. Environ Sci Pollut Res, 21, 4928-4933

Orndorff S.A., Colwell RR., 1980. Microbial transformation of kepone. Appl Environ Microbiol, 39, 398-406.

PPDB (Pesticide properties database), 2013. <http://sitem.herts.ac.uk/aeru/footprint/index2.htm>.

Regulation EC 1107/2009, 2009. Regulation (EC) No 1107/2009 of the European Parliament and of the Council of 21 October 2009 concerning the placing of plant protection products on the market and repealing Council Directives 79/ 117/EEC and 91/414/EEC. 
559

560

561

562

563

564

565

566

567

568

569

570

571

572

573

574

575

576

577

578

579

Roberts T.R., Huston D.H., 1999. Metabolic Pathways of Agrochemicals Part 2 Insecticides and Fungicides. The Royal Society of Chemistry Information Services Cambridge, UK.

Servien R., Mamy L., Li Z., Rossard V., Latrille E., Bessac F., Patureau D., Benoit P., 2014. TyPol - A new methodology for organic compounds clustering based on their molecular characteristics and environmental behaviour. Chemosphere, 111, 613-622.

Sakakibara F., Takagi K., Kataoka R., Kiyota H., Sato Y., Okada S., 2011. Isolation and identification of dieldrin-degrading Pseudonocardia sp strain KSF27 using a soilcharcoal perfusion method with aldrin trans-diol as a structural analog of dieldrin. Biochem Biophys Res Commun, 411(1), 76-81.

Schanke C.A., Wackett L.P., 1992. Environmental reductive elimination reactions of polychlorinated ethanes mimicked by transition-metal coenzymes. Environ. Sci. Technol. 26: 830-833.

Subba-Rao R.V., Alexander M., 1985. Products formed from analogs of 1,1,1-trichloro2,2-bis-(p-chlorophenyl)ethane (DDT) TPs by Pseudomonas putida. Appl Environ Microbiol 33:101-108.

Tenenhaus M., 1998. In: La regression, P.L.S. (Ed.), Théorie et Pratique. Technip, Paris.

Wold S., 1978. Cross-validation estimation of the number of components in factor and principal component analysis. Technometrics 24, 397- 405. 
Table 1

Degradation reactions for different organochlorine pesticides and corresponding transformation products (TP). OX: Oxidation; EpOX: epoxidation; Hyox: hydroxylation; Rdn: reduction; Hygn: hydrogenation; Hys: hydrolysis; DeX: dehalogenation; R-DeCl: reactive dechlorination; Dehys: dehydrolysis; Phos: photolysis; ReAm: rearrangement. When there was no referenced CAS, a number was created according to the following format: CAS number of the parent-INRA-i (i represents the number of the degradation product among all degradation products of the parent compound)

\begin{tabular}{|c|c|c|c|c|c|c|c|c|c|c|c|c|c|c|}
\hline$\overline{\text { Parent compound (PC) }}$ & CAS PC & Transformation product (TP) & CAS TP & OX & EpOX & HyOX & Rdn & Hygn & Hys & DeX & R-DeCl & Dehys & Phos & ReAm \\
\hline \multirow[t]{10}{*}{ DDT } & $50-29-3$ & DDD & 72-54-8 & & & & & $\mathrm{x}$ & & $\mathrm{x}$ & & & & \\
\hline & & $\mathrm{p}, \mathrm{p}^{\prime}-\mathrm{DDE}$ & $72-55-9$ & & & & $\mathrm{x}$ & & & $\mathrm{x}$ & $\mathrm{x}$ & & & \\
\hline & & 4,4'-dichlorobenzophenone & $90-98-2$ & $\mathrm{x}$ & & & & & & $\mathrm{x}$ & & & $\mathrm{x}$ & \\
\hline & & 4,4'-dichlorodiphenylacetic acid & 90-98-2-INRA-1 & $\mathrm{x}$ & & & & & & & & $\mathrm{x}$ & & \\
\hline & & bis(4-chlorophenyl)acetonitrile & 50-29-3-INRA-1 & & & & $\mathrm{x}$ & & & $\mathrm{x}$ & & & & \\
\hline & & DDMU & $1022-22-6$ & & & & $\mathrm{x}$ & & & $\mathrm{x}$ & $\mathrm{x}$ & & & \\
\hline & & 4-chlorophenylacetic acid & $1878-66-6$ & $\mathrm{x}$ & & $\mathrm{x}$ & & & & & & & & \\
\hline & & $\begin{array}{l}\text { o,p'-DDE } \\
\text { 1-(2-chlorophenyl)-1-(4-chlorophenyl)-2- }\end{array}$ & $3424-82-6$ & & & & $\mathrm{x}$ & & & $\mathrm{x}$ & $\mathrm{x}$ & & & $\mathrm{x}$ \\
\hline & & choroethylene & 50-29-3-INRA-2 & & & & $\mathrm{x}$ & $\mathrm{x}$ & & $\mathrm{x}$ & $\mathrm{x}$ & & & $\mathrm{x}$ \\
\hline & & Dicofol & $115-32-2$ & $\mathrm{x}$ & & $\mathrm{x}$ & & & & & & & & \\
\hline \multirow[t]{5}{*}{ Hexachlorobenzene } & $118-74-1$ & Pentachlorobenzene & $608-93-5$ & & & & $\mathrm{x}$ & & & $\mathrm{x}$ & & & $\mathrm{x}$ & \\
\hline & & 1,2,3,4-tetrachlorobenzene & $634-66-2$ & & & & $\mathrm{x}$ & & & $\mathrm{x}$ & & & & \\
\hline & & 1,2,4,5-tetrachlorobenzene & $95-94-3$ & & & & $\mathrm{x}$ & & & $\mathrm{x}$ & & & & \\
\hline & & 1,2,3,5-tetrachlorobenzene & $634-90-2$ & & & & $\mathrm{x}$ & & & $\mathrm{x}$ & & & $\mathrm{x}$ & \\
\hline & & 1,2,4-trichlorobenzene & $120-82-1$ & & & & $\mathrm{x}$ & & & $\mathrm{x}$ & & & & \\
\hline \multirow[t]{5}{*}{ Endosulfan } & $115-29-7$ & Endosulfan diol & $218-467-6$ & & & & & & $\mathrm{x}$ & & & & & \\
\hline & & Endosulfan sulfate & $1031-07-8$ & & & & & & $\mathrm{x}$ & & & & & \\
\hline & & Endosulfan ether & $33-69-52-6$ & $\mathrm{x}$ & & & & & & & & & & \\
\hline & & Endosulfan hydroxyether & $1021-19-8$ & $\mathrm{x}$ & & & & & & & & & & \\
\hline & & Endosulfan lactone & $3868-61-9$ & $\mathrm{x}$ & & & & & & & & & & \\
\hline
\end{tabular}




\begin{tabular}{|c|c|c|c|c|c|c|c|c|c|c|c|c|c|c|}
\hline Parent compound (PC) & CAS PC & Transformation product (TP) & CAS TP & $\mathbf{O X}$ & EpOX & HyOX & Rdn & Hygn & Hys & DeX & R-DeCI & Dehys & Phos & ReAm \\
\hline \multirow[t]{9}{*}{ Chlordane } & $57-74-9$ & Heptachlor & $76-44-8$ & & & & & & & $\mathrm{x}$ & $\mathrm{x}$ & & & \\
\hline & & Heptachlor epoxide & $1024-57-3$ & $\mathrm{x}$ & $\mathrm{x}$ & & & & & & & & & \\
\hline & & 1-chloro-2-hydroxychlordene chlorohydrin & 57-74-9-INRA-1 & & & $\mathrm{x}$ & & & $\mathrm{x}$ & $\mathrm{x}$ & & & & \\
\hline & & 1-chloro-dihydrochlordene & 57-74-9-INRA-2 & & & & & $\mathrm{x}$ & & $\mathrm{x}$ & & & & \\
\hline & & $\begin{array}{l}\text { 3,4,5,6,7,8,8-heptachloro-2,3,3a,4,7,7a- } \\
\text { hexahydro-1H-4,7-methanoindene-1,2-diol }\end{array}$ & 57-74-9-INRA-3 & & & $\mathrm{x}$ & & & & & & & & \\
\hline & & 1,2-dichlorochlordane & 57-74-9-INRA-4 & & & & & & & & & $\mathrm{x}$ & & \\
\hline & & 1-exo-hydroxy-2-chlorochlordene & 57-74-9-INRA-5 & & & $\mathrm{x}$ & & & & & & & & \\
\hline & & Chlordene chlorohydrin & $37571-87-2$ & & & & & $\mathrm{x}$ & & & & & & \\
\hline & & Oxychlordane & $27304-13-8$ & $\mathrm{x}$ & $\mathrm{x}$ & & & & & & & & & \\
\hline \multirow[t]{4}{*}{ Biphenyl } & $92-51-3$ & 2-hydroxybiphenyl & $90-43-7$ & $\mathrm{x}$ & $\mathrm{x}$ & $\mathrm{x}$ & & & & & & & & \\
\hline & & 3-hydroxybiphenyl & $580-51-8$ & $\mathrm{x}$ & $\mathrm{x}$ & $\mathrm{x}$ & & & & & & & & \\
\hline & & 2,3-dihydro-2,3-dihydroxybiphenyl & $34244-66-1$ & $\mathrm{x}$ & & & & & $\mathrm{x}$ & & & & & \\
\hline & & 2,3-dihydroxybiphenyl & $1133-63-7$ & & & & $\mathrm{x}$ & & & & & & & \\
\hline \multirow[t]{6}{*}{ Heptachlor } & $76-44-8$ & 1-hydroxychlordene & $24009-05-0$ & & & & & & $\mathrm{x}$ & & & & & \\
\hline & & Chlordene & $3734-48-3$ & & & & & & & $\mathrm{x}$ & & & & \\
\hline & & Chlordene epoxide & $6058-23-7$ & $\mathrm{x}$ & $\mathrm{x}$ & & & & & & & & & \\
\hline & & $\begin{array}{l}\text { Heptachlor epoxide } \\
3,4,5,6,7,8,8 \text {-heptachloro-2,3,3a,4,7,7a- }\end{array}$ & $1024-57-3$ & $\mathrm{x}$ & $\mathrm{x}$ & & & & & & & & & \\
\hline & & hexahydro-1H-4,7-methanoindene-1,2-diol & 57-74-9-INRA-3 & & & & & & $\mathrm{x}$ & & & & & \\
\hline & & 1-hydroxy-2,3-epoxychlordene & 1024-57-3-INRA-1 & & & & & & $\mathrm{x}$ & & & & & \\
\hline \multirow[t]{7}{*}{$\mathrm{g}-\mathrm{HCH}$} & $608-73-1$ & Pentachlorcyclohexene & $643-15-2$ & & & & $\mathrm{x}$ & & & $\mathrm{x}$ & $\mathrm{x}$ & & & \\
\hline & & 1,2,4-trichlorobenzene & $120-82-1$ & & & & $\mathrm{x}$ & & & $\mathrm{x}$ & $\mathrm{x}$ & & & \\
\hline & & 1,4-dichlorobenzene & $106-46-7$ & & & & & & & $\mathrm{x}$ & & & & \\
\hline & & 1,2,3-trichlorobenzene & $87-61-6$ & & & & $\mathrm{x}$ & & & $\mathrm{x}$ & $\mathrm{x}$ & & & \\
\hline & & 1,2-dichlorobenzene & $95-50-1$ & & & & & & & $\mathrm{x}$ & & & & \\
\hline & & 2,4,6-trichlorophenol & $88-06-2$ & & & & & & & $\mathrm{x}$ & $\mathrm{x}$ & & & \\
\hline & & 1,2,3,4-tetrachlorobenzene & $634-66-2$ & & & & & & & $\mathrm{x}$ & $\mathrm{x}$ & & & \\
\hline
\end{tabular}




\begin{tabular}{|c|c|c|c|c|c|c|c|c|c|c|c|c|c|c|}
\hline Parent compound (PC) & CAS PC & Transformation product (TP) & CAS TP & $\mathbf{O X}$ & EpOX & HyOX & Rdn & Hygn & Hys & DeX & R-DeCl & Dehys & Phos & ReAm \\
\hline \multirow[t]{20}{*}{ Chlordecone } & $143-50-0$ & 10-hydrochlordecone & 143-50-0-INRA-1 & & & & $\mathrm{x}$ & & & & $\mathrm{x}$ & & & \\
\hline & & 9-hydrochlordecone & 143-50-0-INRA-2 & & & & $\mathrm{x}$ & & & & $\mathrm{x}$ & & & \\
\hline & & 6-hydrochlordecone & 143-50-0-INRA-3 & & & & $\mathrm{x}$ & & & & $\mathrm{x}$ & & & \\
\hline & & 8-hydrochlordecone & 143-50-0-INRA-4 & & & & $\mathrm{x}$ & & & & $\mathrm{x}$ & & & \\
\hline & & cis-8,10-dihydrochlordecone & 143-50-0-INRA-5 & & & & $\mathrm{x}$ & & & & $\mathrm{x}$ & & & \\
\hline & & 3,7-dihydrochlordecone & 143-50-0-INRA-6 & & & & $\mathrm{x}$ & & & & $\mathrm{x}$ & & & \\
\hline & & $8,10,10$-trihydrochlordecone & 143-50-0-INRA-7 & & & & $\mathrm{x}$ & & & & $\mathrm{x}$ & & & \\
\hline & & 3,7,10-trihydrochlordecone & 143-50-0-INRA-8 & & & & $\mathrm{x}$ & & & & $\mathrm{x}$ & & & \\
\hline & & 3,7,10,10-tetrahydrochlordecone & 143-50-0-INRA-9 & & & & $\mathrm{x}$ & & & & $\mathrm{x}$ & & & \\
\hline & & r-3,7,8,10-tetrahydrochlordecone & 143-50-0-INRA-10 & & & & $\mathrm{x}$ & & & & $\mathrm{x}$ & & & \\
\hline & & 3,7,8,10,10-pentahydrochlordecone & 143-50-0-INRA-11 & & & & $\mathrm{x}$ & & & & $\mathrm{x}$ & & & \\
\hline & & 2,3,7,8,10,10-hexahydrochlordecone & 143-50-0-INRA-12 & & & & $\mathrm{x}$ & & & & $\mathrm{x}$ & & & \\
\hline & & 2,3,7,8,9,10,10-heptahydrochlordecone & 143-50-0-INRA-13 & & & & $\mathrm{x}$ & & & & $\mathrm{x}$ & & & \\
\hline & & $1,2,3,7,8,9,10,10$-Octahydrochlordecone & 143-50-0-INRA-14 & & & & $\mathrm{x}$ & & & & $\mathrm{x}$ & & & \\
\hline & & $1,2,3,4,6,7,8,9,10$-nonahydrochlordecone & 143-50-0-INRA-15 & & & & $\mathrm{x}$ & & & & $\mathrm{x}$ & & & \\
\hline & & 2,3,4,6,7,8,9,10,10-nonahydrochlordecone & 143-50-0-INRA-16 & & & & $\mathrm{x}$ & & & & $\mathrm{x}$ & & & \\
\hline & & $1,2,3,6,7,8,9,10,10$-nonahydrochlordecone & 143-50-0-INRA-17 & & & & $\mathrm{x}$ & & & & $\mathrm{x}$ & & & \\
\hline & & $1,3,4,6,7,8,9,10,10$-nonahydrochlordecone & 143-50-0-INRA-18 & & & & $\mathrm{x}$ & & & & $\mathrm{x}$ & & & \\
\hline & & Decahydrochlordecone & 143-50-0-INRA-19 & & & & $\mathrm{x}$ & & & & $\mathrm{x}$ & & & \\
\hline & & Chlordecol & 143-50-0-INRA-20 & $\mathrm{x}$ & & $\mathrm{x}$ & & & & & $\mathrm{x}$ & & & \\
\hline
\end{tabular}


Table 2

Chlorinated compounds inputted in TyPol with CAS numbers, names, chemical formulae and chemical families. The parent CAS is given in case of transformation products (PCB: polychlorinated biphenyls, PCDF: polychlorinated dibenzofurans, PCDD: polychlorinated dibenzodioxins).

\begin{tabular}{|c|c|c|c|c|}
\hline CAS & Name & Chemical formula & Chemical family & Parent CAS \\
\hline $115-29-7$ & Endosulfan & $\mathrm{C}_{9} \mathrm{H}_{6} \mathrm{C}_{16} \mathrm{O}_{3} \mathrm{~S}$ & Organochlorine & \\
\hline $1031-07-8$ & Endosulfan sulfate & $\mathrm{C}_{9} \mathrm{H}_{6} \mathrm{C}_{16} \mathrm{O}_{4} \mathrm{~S}$ & Organochlorine & $115-29-7$ \\
\hline $118-74-1$ & Hexachlorobenzene & $\mathrm{C}_{6} \mathrm{Cl}_{6}$ & Organochlorine & \\
\hline $143-50-0$ & Chlordecone & $\mathrm{C} 10 \mathrm{Cl} 10 \mathrm{O}$ & Organochlorine & \\
\hline 143-50-0-INRA-1 & 10-Hydrochlordecone & $\mathrm{C} 10 \mathrm{HCl} 9 \mathrm{O}$ & Organochlorine & $143-50-0$ \\
\hline 143-50-0-INRA-10 & r-3,7,8,t,10-Tetrahydrochlordecone & $\mathrm{C} 10 \mathrm{H} 4 \mathrm{Cl} 6 \mathrm{O}$ & Organochlorine & $143-50-0$ \\
\hline 143-50-0-INRA-11 & 3,7,8,10,10-Pentahydrochlordecone & $\mathrm{C} 10 \mathrm{H} 5 \mathrm{Cl} 5 \mathrm{O}$ & Organochlorine & $143-50-0$ \\
\hline 143-50-0-INRA-12 & $2,3,7,8,10,10$-Hexahydrochlordecone & $\mathrm{C} 10 \mathrm{H} 6 \mathrm{Cl} 14 \mathrm{O}$ & Organochlorine & $143-50-0$ \\
\hline 143-50-0-INRA-13 & $2,3,7,8,9,10,10$-Heptahydrochlordecone & $\mathrm{C} 10 \mathrm{H} 7 \mathrm{Cl} 3 \mathrm{O}$ & Organochlorine & $143-50-0$ \\
\hline 143-50-0-INRA-14 & $1,2,3,7,8,9,10,10$-Octahydrochlordecone & $\mathrm{C} 10 \mathrm{H} 8 \mathrm{Cl} 2 \mathrm{O}$ & Organochlorine & $143-50-0$ \\
\hline 143-50-0-INRA-15 & $1,2,3,4,6,7,8,9,10$-Nonahydrochlordecone & $\mathrm{C} 10 \mathrm{H} 9 \mathrm{Cl} 1 \mathrm{O}$ & Organochlorine & $143-50-0$ \\
\hline 143-50-0-INRA-16 & $2,3,4,6,7,8,9,10,10$-Nonahydrochlordecone & $\mathrm{C} 10 \mathrm{H} 9 \mathrm{Cl} 1 \mathrm{O}$ & Organochlorine & $143-50-0$ \\
\hline 143-50-0-INRA-17 & $1,2,3,6,7,8,9,10,10$-Nonahydrochlordecone & $\mathrm{C} 10 \mathrm{H} 9 \mathrm{Cl} 1 \mathrm{O}$ & Organochlorine & $143-50-0$ \\
\hline 143-50-0-INRA-18 & $1,3,4,6,7,8,9,10,10$-Nonahydrochlordecone & $\mathrm{C} 10 \mathrm{H} 9 \mathrm{Cl} 1 \mathrm{O}$ & Organochlorine & $143-50-0$ \\
\hline 143-50-0-INRA-19 & Decahydrochlordecone & $\mathrm{C} 10 \mathrm{H} 10 \mathrm{O}$ & Organochlorine & $143-50-0$ \\
\hline 143-50-0-INRA-2 & 9-Hydrochlordecone & $\mathrm{C} 10 \mathrm{HCl} 9 \mathrm{O}$ & Organochlorine & $143-50-0$ \\
\hline 143-50-0-INRA-20 & Chlordecol & $\mathrm{C} 10 \mathrm{H} 2 \mathrm{Cl} 10 \mathrm{O}$ & Organochlorine & $143-50-0$ \\
\hline 143-50-0-INRA-3 & 6-Hydrochlordecone & $\mathrm{C} 10 \mathrm{HCl} 9 \mathrm{O}$ & Organochlorine & $143-50-0$ \\
\hline 143-50-0-INRA-4 & 8-Hydrochlordecone & $\mathrm{C} 10 \mathrm{HCl} 9 \mathrm{O}$ & Organochlorine & $143-50-0$ \\
\hline 143-50-0-INRA-5 & cis-8,10-Dihydrochlordecone & $\mathrm{C} 10 \mathrm{H} 2 \mathrm{Cl} 18 \mathrm{O}$ & Organochlorine & $143-50-0$ \\
\hline 143-50-0-INRA-6 & 3,7-Dihydrochlordecone & $\mathrm{C} 10 \mathrm{H} 2 \mathrm{Cl} 8 \mathrm{O}$ & Organochlorine & $143-50-0$ \\
\hline 143-50-0-INRA-7 & $8,10,10$-Trihydrochlordecone & $\mathrm{C} 10 \mathrm{H} 3 \mathrm{Cl} 7 \mathrm{O}$ & Organochlorine & $143-50-0$ \\
\hline 143-50-0-INRA-8 & 3,7,10-Trihydrochlordecone & $\mathrm{C} 10 \mathrm{H} 3 \mathrm{Cl} 7 \mathrm{O}$ & Organochlorine & $143-50-0$ \\
\hline 143-50-0-INRA-9 & 3,7,10,10-Tetrahydrochlordecone & $\mathrm{C} 10 \mathrm{H} 4 \mathrm{Cl} 6 \mathrm{O}$ & Organochlorine & $143-50-0$ \\
\hline $2385-85-5$ & Mirex & $\mathrm{C} 10 \mathrm{Cl12}$ & Organochlorine & \\
\hline 4234-79-1 & Kelevan & $\mathrm{C} 17 \mathrm{H} 12 \mathrm{Cl} 10 \mathrm{O} 4$ & Organochlorine & \\
\hline $50-29-3$ & p,p'-DDT & C14H9Cl5 & Organochlorine & \\
\hline 72-54-8 & DDD & $\mathrm{C} 14 \mathrm{H} 10 \mathrm{Cl} 4$ & Organochlorine & $50-29-3$ \\
\hline $72-55-9$ & DDE & $\mathrm{C} 14 \mathrm{H} 8 \mathrm{Cl} 4$ & Organochlorine & $50-29-3$ \\
\hline $58-89-9$ & Lindane & C6H6Cl6 & Organochlorine & \\
\hline $608-73-1$ & Hexachlorocyclohexane & C6H6Cl6 & Organochlorine & \\
\hline 107534-96-3 & Tebuconazole & $\mathrm{C} 16 \mathrm{H} 22 \mathrm{ClN} 3 \mathrm{O}$ & Triazole & \\
\hline 107534-96-3-INRA-1 & M1-Tebuconazole & $\mathrm{C} 16 \mathrm{H} 22 \mathrm{ClN} 3 \mathrm{O} 2$ & Triazole metabolite & $107534-96-3$ \\
\hline 107534-96-3-INRA-10 & M10-Tebuconazole & $\mathrm{C} 16 \mathrm{H} 22 \mathrm{ClN} 3 \mathrm{O} 3$ & Triazole metabolite & $107534-96-3$ \\
\hline 107534-96-3-INRA-11 & M11-Tebuconazole & $\mathrm{C} 16 \mathrm{H} 20 \mathrm{ClN} 3 \mathrm{O} 2$ & Triazole metabolite & $107534-96-3$ \\
\hline 107534-96-3-INRA-12 & M12-Tebuconazole & $\mathrm{C} 16 \mathrm{H} 20 \mathrm{ClN} 3 \mathrm{O} 2$ & Triazole metabolite & $107534-96-3$ \\
\hline
\end{tabular}


107534-96-3-INRA-13 107534-96-3-INRA-14 107534-96-3-INRA-16 107534-96-3-INRA-2 107534-96-3-INRA-24 107534-96-3-INRA-25 107534-96-3-INRA-26 107534-96-3-INRA-3

107534-96-3-INRA-4 107534-96-3-INRA-5 107534-96-3-INRA-6 107534-96-3-INRA-65 107534-96-3-INRA-67 107534-96-3-INRA-76 107534-96-3-INRA-8 107534-96-3-INRA-9

119446-68-3

131983-72-7

131983-72-7-INRA-1

131983-72-7-INRA-2

133855-98-8

94361-06-5

$14168-01-5$

1715-40-8

$2550-75-6$

$297-78-9$

309-00-2

465-73-6

$57-74-9$

27304-13-8

60-57-1

76-44-8

1024-57-3

8001-35-2

15972-60-8

1918-16-7

34256-82-1

51218-45-2

67129-08-2

$122-34-9$
M13-Tebuconazole

M14-Tebuconazole

M16-Tebuconazole

M2-Tebuconazole

M24-Tebuconazole

M25-Tebuconazole

M26-Tebuconazole

M3-Tebuconazole

M4-Tebuconazole

M5-Tebuconazole

M6-Tebuconazole

M65-Tebuconazole

M67-Tebuconazole

M7-Tebuconazole

M76-Tebuconazole

M8-Tebuconazole

M9-Tebuconazole

Difenoconazole

Triticonazole

(1R,3R,E)-3-(4-chlorobenzylidene)-5,5-dimethyl-1-((1H)-1,2,4-triazol-1ylmethyl)-cyclopentan-1,3-diol

(E)-2-(4-chlorobenzylidene)-5,5-dimethyl-1-((1H)-1,2,4-triazol-1-

ylmethyl)-cyclopentan-1,3-diol

Epoxiconazole

Cyproconazole

Dilor

Bromocyclene

Chlorbicyclene

Isobenzane

Aldrine

Isodrine

Chlordane

Oxychlordane

Dieldrine

Heptachlore

Heptachlore epoxide

Toxaphene

Alachlor

Propachlor

Acetochlor

Metolachlor

Metazachlor

Simazine
C16H20ClN3O2

C16H20CIN3O2

$\mathrm{C} 16 \mathrm{H} 20 \mathrm{ClN} 3 \mathrm{O} 2$

$\mathrm{C} 16 \mathrm{H} 22 \mathrm{ClN} 3 \mathrm{O} 2$

C15H20ClN3O

C13H16ClN3O

C12H14ClN3O

$\mathrm{C} 16 \mathrm{H} 22 \mathrm{ClN} 3 \mathrm{O} 2$

$\mathrm{C} 16 \mathrm{H} 22 \mathrm{ClN} 3 \mathrm{O} 3$

$\mathrm{C} 16 \mathrm{H} 22 \mathrm{ClN} 3 \mathrm{O} 2$

$\mathrm{C} 16 \mathrm{H} 22 \mathrm{ClN} 3 \mathrm{O} 2$

C15H21CIN2O

C15H21ClN2O

$\mathrm{C} 16 \mathrm{H} 22 \mathrm{ClN} 3 \mathrm{O} 2$

$\mathrm{C} 7 \mathrm{H} 5 \mathrm{ClO} 2$

$\mathrm{C} 16 \mathrm{H} 22 \mathrm{ClN} 3 \mathrm{O} 2$

$\mathrm{C} 16 \mathrm{H} 22 \mathrm{ClN} 3 \mathrm{O} 2$

$\mathrm{C} 19 \mathrm{H} 17 \mathrm{Cl} 2 \mathrm{~N} 3 \mathrm{O} 3$

C17H20CIN3

$\mathrm{C} 17 \mathrm{H} 20 \mathrm{ClN} 3 \mathrm{O} 2$

C17H20CIN3O2

C17H13ClFN3O

C15H18CIN3O

$\mathrm{C} 10 \mathrm{H} 7 \mathrm{Cl} 7$

$\mathrm{C} 8 \mathrm{H} 5 \mathrm{BrCl} 6$

$\mathrm{C} 9 \mathrm{H} 6 \mathrm{Cl} 8$

$\mathrm{C} 9 \mathrm{H} 4 \mathrm{Cl} 8 \mathrm{O}$

$\mathrm{C} 12 \mathrm{H} 8 \mathrm{Cl} 6$

$\mathrm{C} 12 \mathrm{H} 8 \mathrm{Cl} 6$

$\mathrm{C} 10 \mathrm{H} 6 \mathrm{Cl} 8$

$\mathrm{C} 10 \mathrm{H} 4 \mathrm{Cl} 8 \mathrm{O}$

$\mathrm{C} 12 \mathrm{H} 8 \mathrm{Cl} 6 \mathrm{O}$

$\mathrm{C} 10 \mathrm{H} 5 \mathrm{Cl} 7$

$\mathrm{C} 10 \mathrm{H} 5 \mathrm{Cl} 7 \mathrm{O}$

$\mathrm{C} 10 \mathrm{H} 8 \mathrm{Cl} 8$

C14H20CINO2

C11H14CINO

$\mathrm{C} 14 \mathrm{H} 20 \mathrm{CINO} 2$

C15H22CINO2

C14H16CIN3O

C7H12ClN5
Triazole metabolite

Triazole metabolite

Triazole metabolite

Triazole metabolite

Triazole metabolite

Triazole metabolite

Triazole metabolite

Triazole metabolite

Triazole metabolite

Triazole metabolite

Triazole metabolite

Triazole metabolite

Triazole metabolite

Triazole metabolite

Triazole metabolite

Triazole metabolite

Triazole metabolite

Triazole

Triazole

Triazole metabolite

Triazole metabolite

Triazole

Triazole

Chloro-bicycloheptene

Chloro-bicycloheptene

Chloro-bicycloheptene

Chloro-bicycloheptene

Chloro-bicycloheptene

Chloro-bicycloheptene

Chloro-bicycloheptene

Chloro-bicycloheptene metabolite

Chloro-bicycloheptene

Chloro-bicycloheptene

Chloro-bicycloheptene

Chloro-bicycloheptene

Chloroacetamide

Chloroacetamide

Chloroacetamide

Chloroacetamide

Chloroacetamide

Triazine
107534-96-3

$107534-96-3$

107534-96-3

$107534-96-3$

107534-96-3

107534-96-3

107534-96-3

107534-96-3

107534-96-3

107534-96-3

107534-96-3

107534-96-3

107534-96-3

$107534-96-3$

107534-96-3

107534-96-3

107534-96-3

131983-72-7

$131983-72-7$

$57-74-9$

76-44-8, 57-74-9 


\begin{tabular}{|c|c|c|c|c|}
\hline $1912-24-9$ & Atrazine & C8H14ClN5 & Triazine & \\
\hline $21725-46-2$ & Cyanazine & C9H13CIN6 & Triazine & \\
\hline $5915-41-3$ & Terbuthylazine & C9H16CIN5 & Triazine & \\
\hline $15545-48-9$ & Chlortoluron & $\mathrm{C} 10 \mathrm{H} 13 \mathrm{ClN} 2 \mathrm{O}$ & Urea & \\
\hline $1746-81-2$ & Monolinuron & $\mathrm{C} 9 \mathrm{H} 11 \mathrm{ClN} 2 \mathrm{O} 2$ & Urea & \\
\hline $555-37-3$ & Neburon & $\mathrm{C} 12 \mathrm{H} 16 \mathrm{Cl} 2 \mathrm{~N} 2 \mathrm{O}$ & Urea & \\
\hline $330-54-1$ & Diuron & $\mathrm{C} 9 \mathrm{H} 10 \mathrm{Cl} 2 \mathrm{~N} 2 \mathrm{O}$ & Phenylurea & \\
\hline $95-76-1$ & 3,4-dichloroaniline & $\mathrm{C} 6 \mathrm{H} 5 \mathrm{Cl} 2 \mathrm{~N}$ & Phenylurea metabolite & $330-54-1$ \\
\hline $2327-02-8$ & 3,4-dichlorophenyl urea & $\mathrm{C} 7 \mathrm{H} 6 \mathrm{Cl} 2 \mathrm{~N} 2 \mathrm{O}$ & Phenylurea metabolite & $330-54-1$ \\
\hline $3567-62-2$ & 1-(3,4-dichlorophenyl)-3-methylurea & $\mathrm{C} 8 \mathrm{H} 8 \mathrm{Cl} 2 \mathrm{~N} 2 \mathrm{O}$ & Phenylurea metabolite & $330-54-1$ \\
\hline $52315-07-8$ & Cypermethrin & $\mathrm{C} 22 \mathrm{H} 19 \mathrm{Cl} 2 \mathrm{NO} 3$ & Pyrethroid & \\
\hline $52645-53-1$ & Permethrin & $\mathrm{C} 21 \mathrm{H} 20 \mathrm{Cl} 2 \mathrm{O} 3$ & Pyrethroid & \\
\hline $68359-37-5$ & Cyfluthrin & $\mathrm{C} 22 \mathrm{H} 18 \mathrm{Cl} 2 \mathrm{FNO} 3$ & Pyrethroid & \\
\hline 68359-37-5-INRA-1 & 3-(2,2-dichlorovinyl)-2,2-dimethylcyclopropanecarboxylic acid & $\mathrm{C} 8 \mathrm{H} 10 \mathrm{Cl} 2 \mathrm{O} 2$ & Pyrethroid metabolite & $68359-37-5$ \\
\hline $32809-16-8$ & Procymidone & $\mathrm{C} 13 \mathrm{H} 11 \mathrm{Cl} 2 \mathrm{NO} 2$ & Dicarboximide & \\
\hline $36734-19-7$ & Iprodione & $\mathrm{C} 13 \mathrm{H} 13 \mathrm{Cl} 2 \mathrm{~N} 3 \mathrm{O} 3$ & Dicarboximide & \\
\hline $63637-89-8$ & $\mathrm{~N}$-(3,5-dichlorophenyl)3-isopropyl-2,4-dioxoimidazoline-1-carboxamide & $\mathrm{C} 17 \mathrm{H} 20 \mathrm{ClN} 3 \mathrm{O} 2$ & Dicarboximide metabolite & $36734-19-7$ \\
\hline 7085-19-0 & Mecoprop & $\mathrm{C} 10 \mathrm{H} 11 \mathrm{ClO} 3$ & Aryloxyalkanoic acid & \\
\hline $94-74-6$ & MCPA & $\mathrm{C} 9 \mathrm{H} 9 \mathrm{ClO} 3$ & Aryloxyalkanoic acid & \\
\hline $1570-64-5$ & 2-methyl-4-chlorophenol & $\mathrm{C} 7 \mathrm{H} 7 \mathrm{ClO}$ & Aryloxyalkanoic acid metabolite & $94-74-6$ \\
\hline 27314-13-2 & Norflurazon & $\mathrm{C} 12 \mathrm{H} 9 \mathrm{ClF} 3 \mathrm{~N} 3 \mathrm{O}$ & Pyridazinone & \\
\hline 23576-24-1 & Desmethyl norflurazon & $\mathrm{C} 11 \mathrm{H} 7 \mathrm{ClF} 3 \mathrm{~N} 3 \mathrm{O}$ & Pyridazinone metabolite & 27314-13-2 \\
\hline $133-06-2$ & Captan & $\mathrm{C} 9 \mathrm{H} 8 \mathrm{Cl} 3 \mathrm{NO} 2 \mathrm{~S}$ & Phthalimide & \\
\hline $133-07-3$ & Folpet & $\mathrm{C} 9 \mathrm{H} 4 \mathrm{Cl} 3 \mathrm{NO} 2 \mathrm{~S}$ & Phthalimide & \\
\hline $175013-18-0$ & Pyraclostrobin & C19H18CIN3O4 & Strobilurin & \\
\hline $361377-29-9$ & Fluoxastrobin & $\mathrm{C} 21 \mathrm{H} 16 \mathrm{ClFN} 4 \mathrm{O} 5$ & Strobilurin & \\
\hline $2303-16-4$ & Di-allate & $\mathrm{C} 10 \mathrm{H} 17 \mathrm{Cl} 2 \mathrm{NOS}$ & Thiocarbamate & \\
\hline $2303-17-5$ & Tri-allate & $\mathrm{C} 10 \mathrm{H} 16 \mathrm{Cl} 3 \mathrm{NOS}$ & Thiocarbamate & \\
\hline $1897-45-6$ & Chlorothalonil & $\mathrm{C} 8 \mathrm{Cl} 4 \mathrm{~N} 2$ & Chloronitrile & \\
\hline 1897-45-6-INRA-1 & 4-hydroxy-2,5,6-trichloroisophtalonitrile & $\mathrm{C} 8 \mathrm{HCl} 3 \mathrm{~N} 2 \mathrm{O}$ & Chloronitrile metabolite & $1897-45-6$ \\
\hline $335104-84-2$ & Tembotrione & $\mathrm{C} 17 \mathrm{H} 16 \mathrm{ClF} 3 \mathrm{O} 6 \mathrm{~S}$ & Triketone & \\
\hline $99105-77-8$ & Sulcotrione & $\mathrm{C} 14 \mathrm{H} 13 \mathrm{ClO} 5 \mathrm{~S}$ & Triketone & \\
\hline $94-75-7$ & 2,4-D & $\mathrm{C} 8 \mathrm{H} 6 \mathrm{Cl} 2 \mathrm{O} 3$ & Alkylchlorophenoxy & \\
\hline $709-98-8$ & Propanil & $\mathrm{C} 9 \mathrm{H} 9 \mathrm{Cl} 2 \mathrm{NO}$ & Anilide & \\
\hline $51338-27-3$ & Diclofop-methyl & $\mathrm{C} 16 \mathrm{H} 14 \mathrm{Cl} 2 \mathrm{O} 4$ & Aryloxyphenoxypropionate & \\
\hline $23950-58-5$ & Propyzamide & $\mathrm{C} 12 \mathrm{H} 11 \mathrm{Cl} 2 \mathrm{NO}$ & Benzamide & \\
\hline $1918-00-9$ & Dicamba & $\mathrm{C} 8 \mathrm{H} 6 \mathrm{Cl} 2 \mathrm{O} 3$ & Benzoic acid & \\
\hline $101-21-3$ & Chlorpropham & $\mathrm{C} 10 \mathrm{H} 12 \mathrm{ClNO} 2$ & Carbamate & \\
\hline 74070-46-5 & Aclonifen & $\mathrm{C} 12 \mathrm{H} 9 \mathrm{ClN} 2 \mathrm{O} 3$ & Diphenyl ether & \\
\hline $16672-87-0$ & Ethephon & $\mathrm{C} 2 \mathrm{H} 6 \mathrm{ClO} 3 \mathrm{P}$ & Ethylene generator & \\
\hline
\end{tabular}




$110488-70-5$
$135410-20-7$
$5598-13-0$
$1918-02-1$
$64902-72-3$
$13029-08-8$
$16605-91-7$
$2050-67-1$
$2050-68-2$
$2051-24-3$
$2051-60-7$
$2051-61-8$
$25569-80-6$
$2974-90-5$
$2974-92-7$
$33146-45-1$
$33284-50-3$
$34883-39-1$
$34883-41-5$
$34883-43-7$
$35065-30-6$
$35694-08-7$
$37680-66-3$
$38380-07-3$
$38444-78-9$
$38444-93-8$
$40186-72-9$
$52663-59-9$
$52663-62-4$
$52663-71-5$
$52663-78-2$
$52663-79-3$
$55215-18-4$
$60145-20-2$
$39001-02-0$
$51207-31-9$
$55673-89-7$
$57117-31-4$
$57117-41-6$
$57117-44-9$
$60851-34-5$
$67562-39-4$
$70648-26-9$

Dimethomorph

Acetamiprid

Chlorpyrifos-methyl

Picloram

Chlorsulfuron

2,2'-Dichlorobiphenyle

2,3-Dichlorobiphenyle

3,3'-Dichlorobiphenyle

4,4'-Dichlorobiphenyle

Decachlorobiphenyle

2-Chlorobiphenyle

3-Chlorobiphenyle

2,3'-Dichlorobiphenyle

3,4'-Dichlorobiphenyle

3,4-Dichlorobiphenyle

2,6-Dichlorobiphenyle

2,4-Dichlorobiphenyle

2,5-Dichlorobiphenyle

3,5-Dichlorobiphenyle

2,4'-Dichlorobiphenyle

2,2',3,3',4,4',5-Heptachlorobiphenyle

2,2',3,3',4,4',5,5'-Octachlorobiphenyle

2,2',4-Trichlorobiphenyle

2,2',3,3',4,4'-Hexachlorobiphenyle

2,2',3-Trichlorobiphenyle

2,2',3,3'-Tetrachlorobiphenyle

2,2',3,3',4,4',5,5',6-Nonachlorobiphenyle

2,2',3,4-Tetrachlorobiphenyle

2,2',3,3',4-Pentachlorobiphenyle

2,2',3,3',4,4',6-Heptachlorobiphenyle

2,2',3,3',4,4',5,6-Octachlorobiphenyle

2,2',3,3',4,4',5,6,6'-Nonachlorobiphenyle

$2,2,, 3,3,, 4,5$-Hexachlorobiphenyle

2,2',3,3',5-Pentachlorobiphenyle

OCDF

2,3,7,8-TCDF

1,2,3,4,7,8,9-HpCDF

2,3,4,7,8-PeCDF

$1,2,3,7,8-\mathrm{PeCDF}$

$1,2,3,6,7,8-\mathrm{HxCDF}$

2,3,4,6,7,8-HxCDF

1,2,3,4,6,7,8-HpCDF

$1,2,3,4,7,8-\mathrm{HxCDF}$

\section{C21H22CINO4}

C10H11CIN4

C7H7Cl3NO3PS

$\mathrm{C} 6 \mathrm{H} 3 \mathrm{Cl} 3 \mathrm{~N} 2 \mathrm{O} 2$

C12H12CIN5O4S

$\mathrm{C} 12 \mathrm{H} 8 \mathrm{Cl} 2$

$\mathrm{C} 12 \mathrm{H} 8 \mathrm{Cl} 2$

$\mathrm{C} 12 \mathrm{H} 8 \mathrm{Cl} 2$

$\mathrm{C} 12 \mathrm{H} 8 \mathrm{Cl} 2$

$\mathrm{C} 12 \mathrm{Cl} 10$

$\mathrm{C} 12 \mathrm{H} 9 \mathrm{Cl}$

$\mathrm{C} 12 \mathrm{H} 9 \mathrm{Cl}$

$\mathrm{C} 12 \mathrm{H} 8 \mathrm{Cl} 2$

$\mathrm{C} 12 \mathrm{H} 8 \mathrm{Cl} 2$

$\mathrm{C} 12 \mathrm{H} 8 \mathrm{Cl} 2$

$\mathrm{C} 12 \mathrm{H} 8 \mathrm{Cl} 2$

$\mathrm{C} 12 \mathrm{H} 8 \mathrm{Cl} 2$

$\mathrm{C} 12 \mathrm{H} 8 \mathrm{Cl} 2$

$\mathrm{C} 12 \mathrm{H} 8 \mathrm{Cl} 2$

$\mathrm{C} 12 \mathrm{H} 3 \mathrm{Cl} 7$

$\mathrm{C} 12 \mathrm{H} 2 \mathrm{Cl} 8$

$\mathrm{C} 12 \mathrm{H} 7 \mathrm{Cl} 3$

$\mathrm{C} 12 \mathrm{H} 4 \mathrm{Cl} 6$

$\mathrm{C} 12 \mathrm{H} 7 \mathrm{Cl} 3$

$\mathrm{C} 12 \mathrm{H} 6 \mathrm{Cl} 4$

$\mathrm{C} 12 \mathrm{HCl} 9$

$\mathrm{C} 12 \mathrm{H} 6 \mathrm{Cl} 4$

$\mathrm{C} 12 \mathrm{H} 5 \mathrm{Cl} 5$

$\mathrm{C} 12 \mathrm{H} 3 \mathrm{Cl} 7$

$\mathrm{C} 12 \mathrm{H} 2 \mathrm{Cl} 8$

$\mathrm{C} 12 \mathrm{HCl} 9$

$\mathrm{C} 12 \mathrm{H} 4 \mathrm{Cl} 6$

$\mathrm{C} 12 \mathrm{H} 5 \mathrm{Cl} 5$

$\mathrm{C} 12 \mathrm{Cl} 8 \mathrm{O}$

$\mathrm{C} 12 \mathrm{H} 4 \mathrm{Cl} 4 \mathrm{O}$

$\mathrm{C} 12 \mathrm{HCl} 7 \mathrm{O}$

$\mathrm{C} 12 \mathrm{H} 3 \mathrm{Cl} 5 \mathrm{O}$

$\mathrm{C} 12 \mathrm{H} 3 \mathrm{Cl} 5 \mathrm{O}$

$\mathrm{C} 12 \mathrm{H} 2 \mathrm{Cl} 6 \mathrm{O}$

$\mathrm{C} 12 \mathrm{H} 2 \mathrm{Cl} 6 \mathrm{O}$

$\mathrm{C} 12 \mathrm{HCl} 7 \mathrm{O}$

$\mathrm{C} 12 \mathrm{H} 2 \mathrm{Cl} 6 \mathrm{O}$
Morpholine

Neonicotinoid

Organophosphate

Pyridine

Sulfonylurea

PCB

PCB

PCB

PCB

PCB

PCB

PCB

PCB

PCB

PCB

PCB

PCB

PCB

PCB

PCB

PCB

PCB

PCB

PCB

PCB

PCB

PCB

PCB

PCB

PCB

PCB

PCB

PCDF

PCDF

PCDF

PCDF

PCDF

PCDF

PCDF

PCDF

PCDF 
72918-21-9

1746-01-6

19408-74-3

3268-87-9

35822-46-9

39227-28-6

40321-76-4

57653-85-7
1,2,3,7,8,9-HxCDF

2,3,7,8-Tetrachlorodibenzo-p-dioxine

1,2,3,7,8,9-HxCDD

OCDD

1,2,3,4,6,7,8-HpCDD

$1,2,3,4,7,8-\mathrm{HxCDD}$

$1,2,3,7,8-\mathrm{PeCDD}$

$1,2,3,6,7,8-\mathrm{HxCDD}$
$\mathrm{C} 12 \mathrm{H} 2 \mathrm{Cl} 6 \mathrm{O}$

$\mathrm{C} 12 \mathrm{H} 4 \mathrm{Cl} 4 \mathrm{O} 2$

$\mathrm{C} 12 \mathrm{H} 2 \mathrm{Cl} 6 \mathrm{O} 2$

$\mathrm{C} 12 \mathrm{Cl} 8 \mathrm{O} 2$

$\mathrm{C} 12 \mathrm{HCl} 7 \mathrm{O} 2$

$\mathrm{C} 12 \mathrm{H} 2 \mathrm{Cl} 6 \mathrm{O} 2$

$\mathrm{C} 12 \mathrm{H} 3 \mathrm{Cl} 5 \mathrm{O} 2$

$\mathrm{C} 12 \mathrm{H} 2 \mathrm{Cl} 6 \mathrm{O} 2$
PCDF

PCDD

PCDD

PCDD

PCDD

PCDD

PCDD 


\section{Figure captions}

\section{Fig. 1.}

Graphical representation of the obtained clusters in the two X-axes of the PLS with the molecular descriptors and environmental parameters on all organochlorine compounds - with exception of the putative transformation products of chlordecone for which environmental parameters are unknown.

\section{Fig. 2.}

Circles of correlations of the 'environmental parameters' (in blue) and 'molecular descriptors' (in red) variables on the two main components of the PLS (Comp 1 and Comp 2). C.i-i stands for the connectivity index C.i of order $\mathrm{i}$ ( $\mathrm{i}=0$ to 5), and V.c-i stands for the valence connectivity index V.c of order $\mathrm{i}(\mathrm{i}=0-5)$.

\section{Fig. 3.}

Range of variation (box-and-whisker plots) of the values of the seven 'environmental parameters' considered into TyPol (water solubility $S w$, octanol-water partition coefficient $K o w$, vapor pressure $P_{v a p}$, Henry's law constant $K_{H}$, adsorption coefficient normalized to soil carbon organic content $K o c$, half-life DT50, and bioconcentration factor $B C F$ ) for each cluster after analysis of the 130 chlorinated compounds. Dotted lines represent the limits between: volatile $\left(\log P_{\text {vap }}>1\right)$ and non-volatile compounds $\left(\log P_{\text {vap }}<1\right)$ (FOCUS, 2008); mobile $(\log K o c<2.7)$ and non-mobile compounds $(\log K o c>2.7)$ (McCall et al., 1980); persistent $(\log D T 50>2.25)$ and non-persistent compounds $(\log D T 50<2.25)$ (Regulation EC $1107 / 2009,2009)$, and compounds having $(\log B C F>2)$ or not $(\log B C F<2)$ a potential of bioaccumulation (Regulation EC 1107/ 2009, 2009).

\section{Fig. 4.}

Circles of correlations of the 'molecular descriptors' (in red) variables on the two main components of the PLS (Comp 1 and Comp 2). C.i-i stands for the connectivity index C.i of order $\mathrm{i}(\mathrm{i}=0$ to 5 ), and V.c-i stands for the valence connectivity index V.c of order $\mathrm{i}(\mathrm{i}=0-5)$. PLS realized with the molecular descriptors only - considering all organochlorine compounds including the putative metabolites of chlordecone. 


\section{Fig. 5.}

Graphical representation of the clusters obtained with the 'molecular descriptors' only considering all organochlorine compounds including the putative metabolites of chlordecone.

\section{Fig. 6.}

Filiation's parents-TPs shown on the cluster representation obtained with the molecular descriptors only 




Fig. 1 


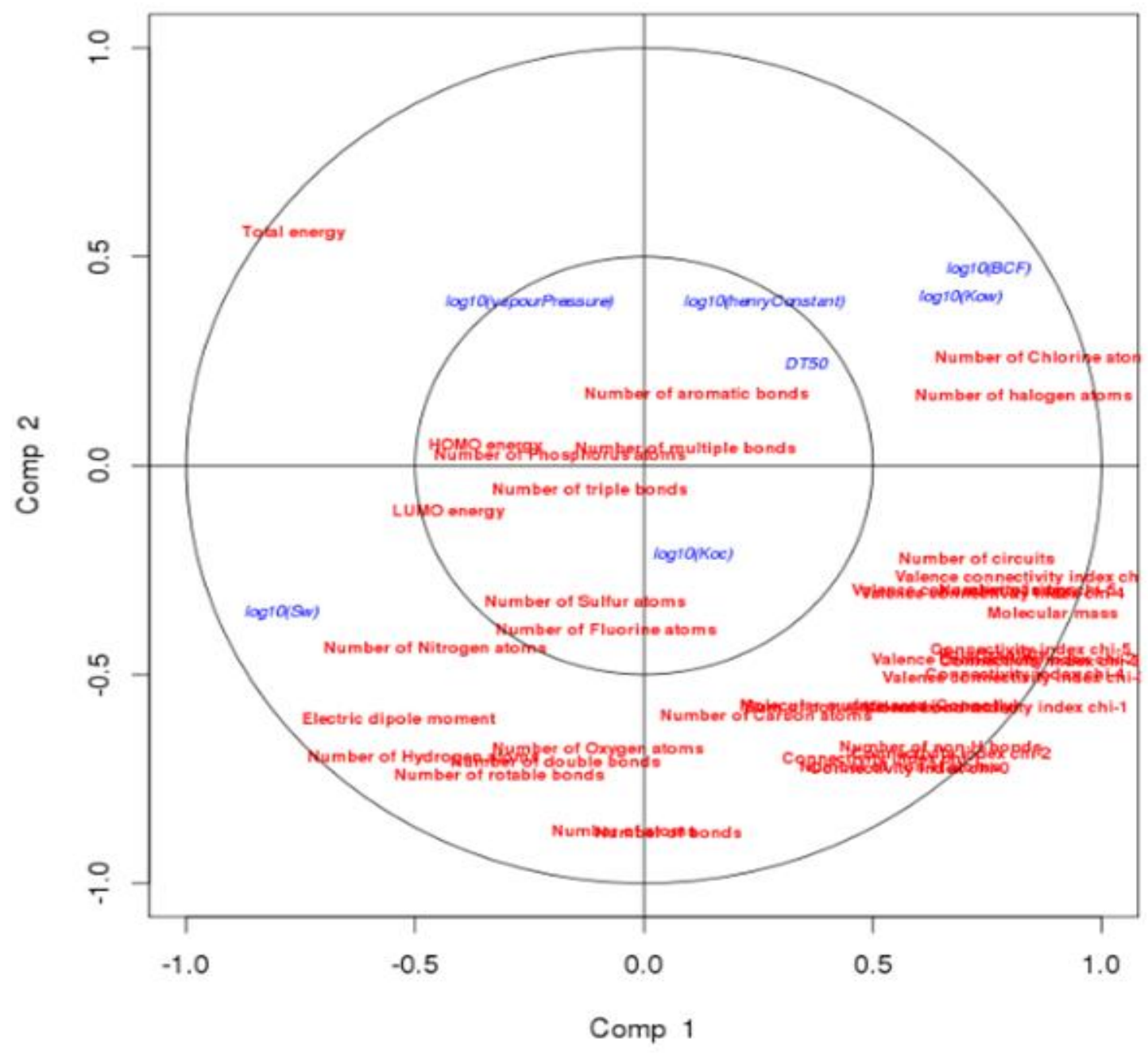

Fig. 2 

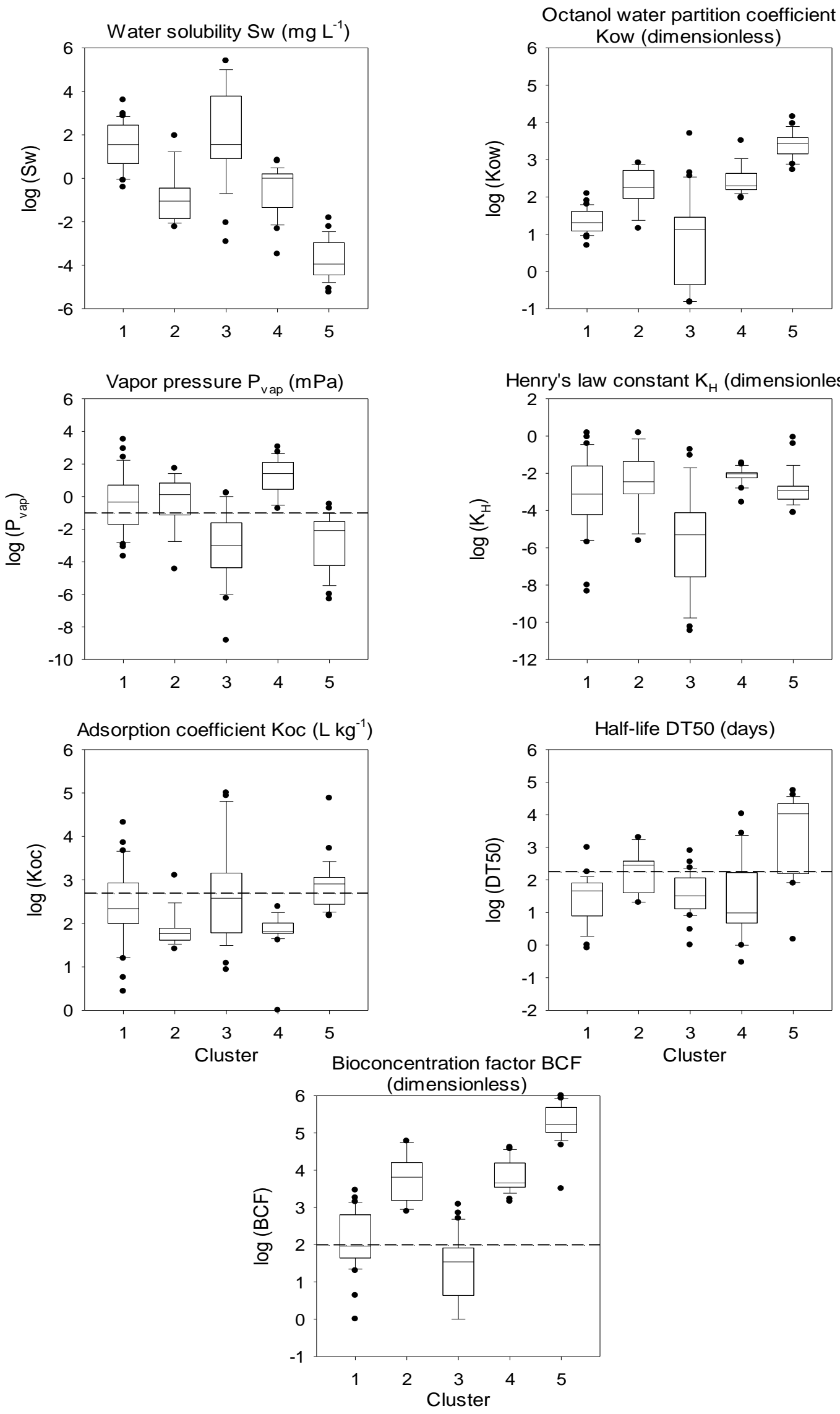

Fig. 3 




Fig. 4 


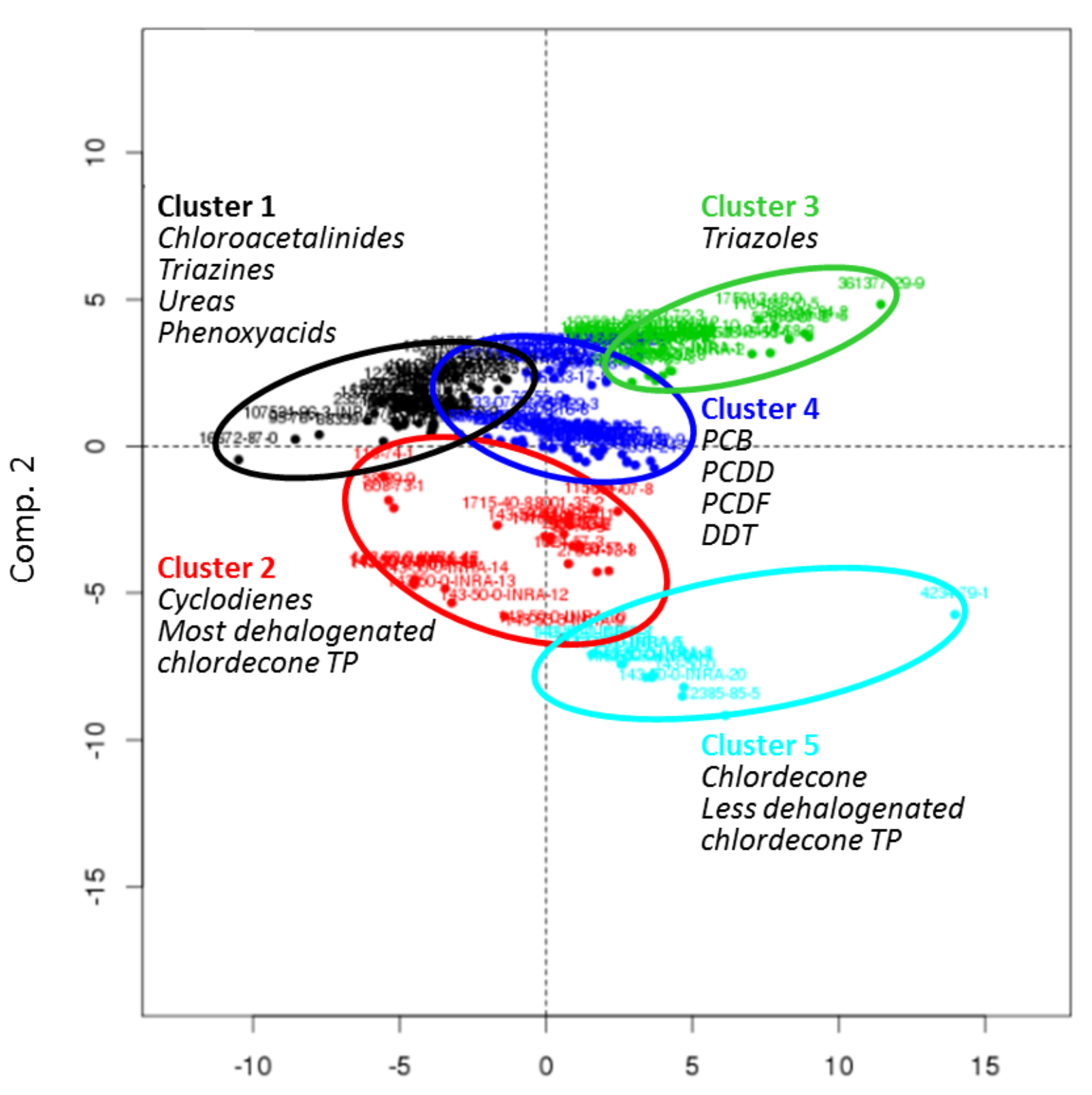

Comp. 1

Fig. 5 


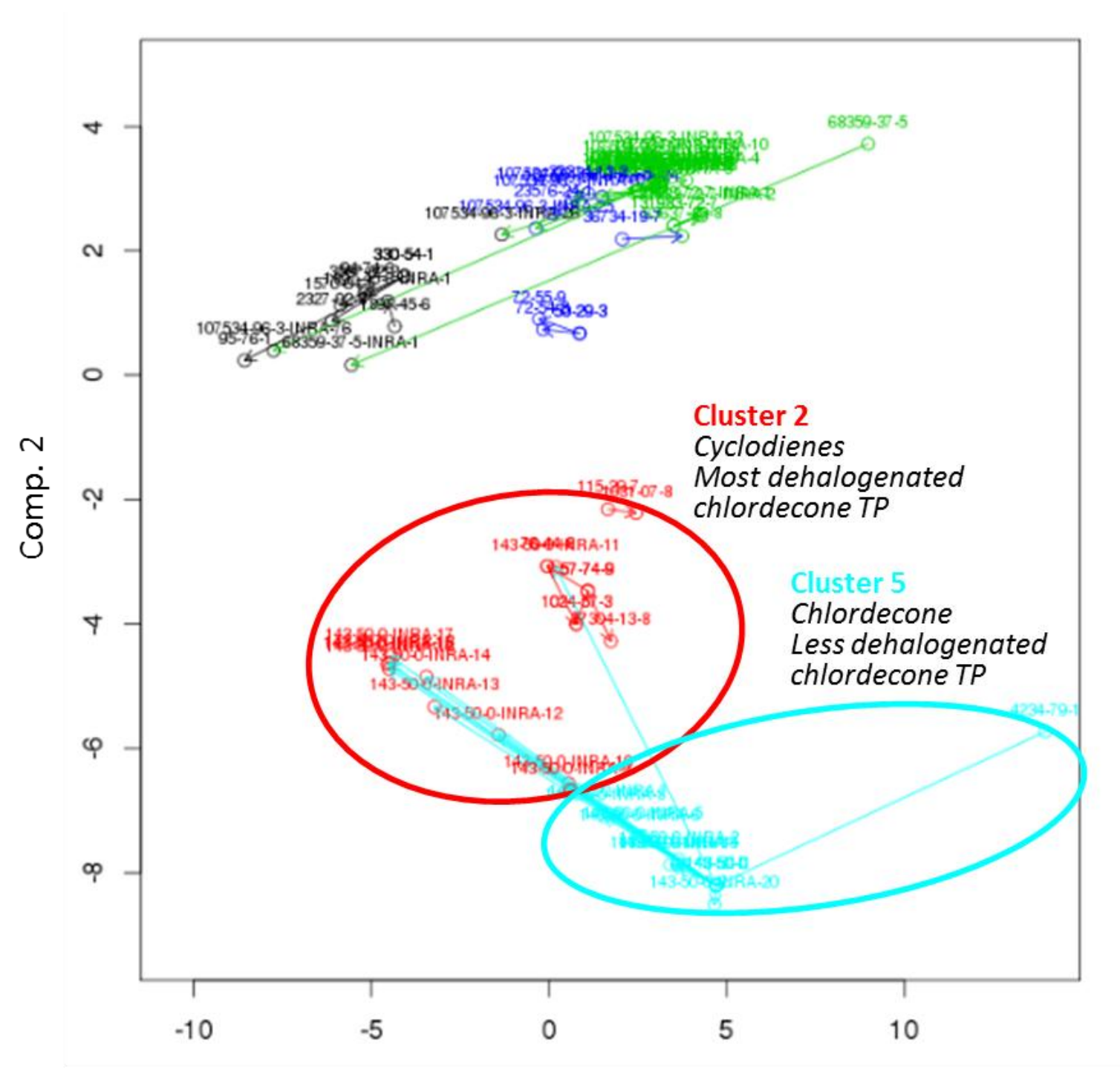

Comp. 1

Fig. 6 